Review

\title{
Bioactive Secondary Metabolites from the Marine Sponge Genus Agelas
}

\author{
Huawei Zhang ${ }^{1, *}$ (D) , Menglian Dong ${ }^{1}$, Jianwei Chen ${ }^{1}$, Hong Wang ${ }^{1}$, Karen Tenney ${ }^{2}$ and \\ Phillip Crews ${ }^{2}$ \\ 1 Department of Pharmaceutical Sciences, Zhejiang University of Technology, Hangzhou 310014, China; \\ baix12012@163.com (M.D.); cjw983617@zjut.edu.cn (J.C.); hongw@zjut.edu.cn (H.W.) \\ 2 Department of Chemistry \& Biochemistry, University of California Santa Cruz, Santa Cruz, CA 95064, USA; \\ ktenney@ucsc.edu (K.T.); pcrews@ucsc.edu (P.C.) \\ * Correspondence: hwzhang@zjut.edu.cn; Tel.: +86-571-8832-0613
}

Received: 19 September 2017; Accepted: 3 November 2017; Published: 8 November 2017

\begin{abstract}
The marine sponge genus Agelas comprises a rich reservoir of species and natural products with diverse chemical structures and biological properties with potential application in new drug development. This review for the first time summarized secondary metabolites from Agelas sponges discovered in the past 47 years together with their bioactive effects.
\end{abstract}

Keywords: marine sponge; Agelas; secondary metabolite; natural product; bioactivity

\section{Introduction}

The search for natural drug candidates from marine organisms is the eternal impetus to pharmaceutical scientists. For the past six decades, marine sponges have been a prolific and chemically diverse source of natural compounds with potential therapeutic application [1,2]. The marine sponge Agelas (Porifera, Demospongiae, Agelasida, Agelasidae) is widely distributed in the marine eco-system and includes at least 19 species (Figure 1): A. axifera, A. cerebrum, A. ceylonica, A. citrina, A. clathrodes, A. conifera, A. dendromorpha, A. dispar, A. gracilis, A. linnaei, A. longissima, A. mauritiana, A. nakamurai, A. nemoechinata, A. oroides, A. sceptrum, A. schmidtii, A. sventres, and A. wiedenmayeri. Since the beginning of the 1970s, many research groups around the world have carried out chemical investigation on Agelas spp., resulting in fruitful achievements. Their studies revealed that Agelas sponges harbor many bioactive secondary metabolites, including alkaloids (especially bromopyrrole derivatives), terpenoids, glycosphingolipids, carotenoids, fatty acids and meroterpenoids [3]. These natural products are an attractive resource for drug candidates due to their rich chemodiversity and interesting biological activities. 


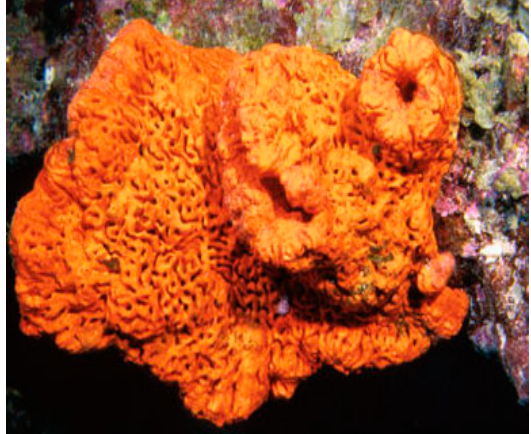

Agelas clathrodes

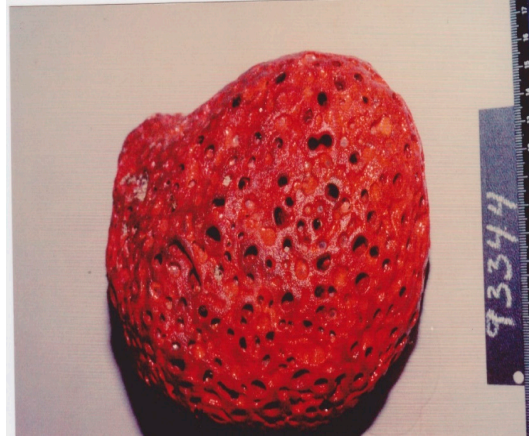

Agelas dispar

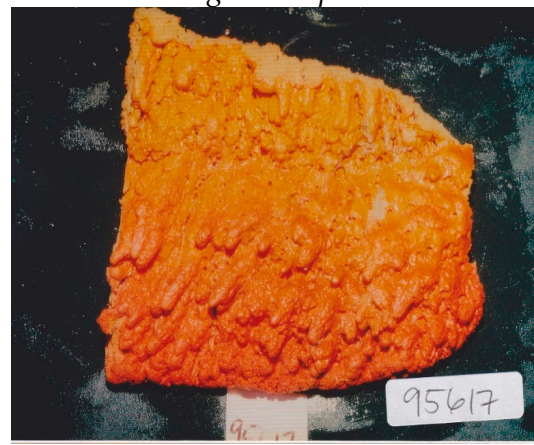

Agelas mauritiana

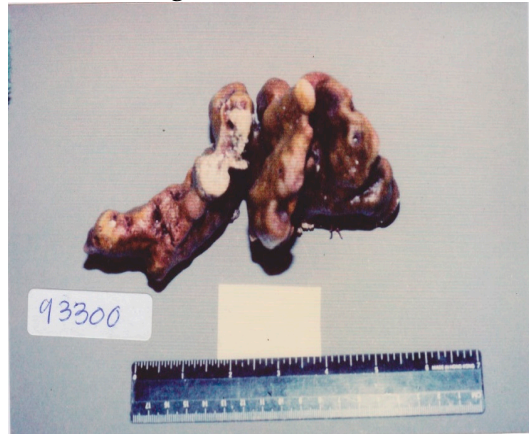

Agelas wiendermayeri

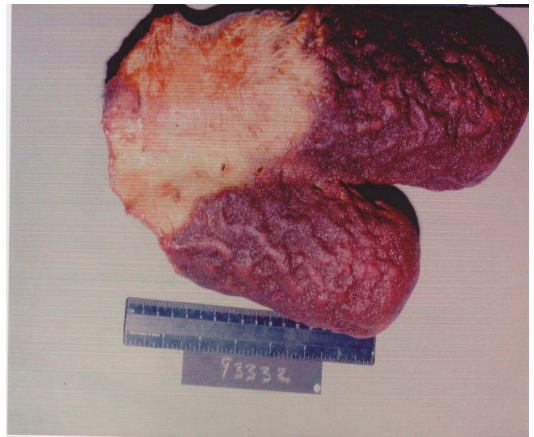

Agelas conifera

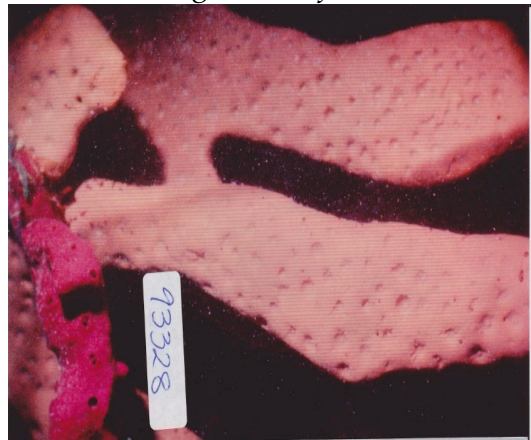

Agelas inequalis

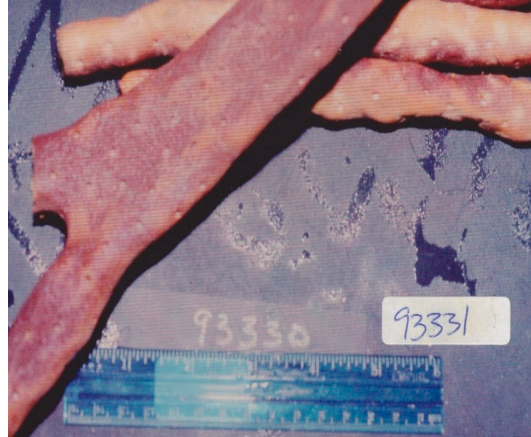

Agelas sceptrum

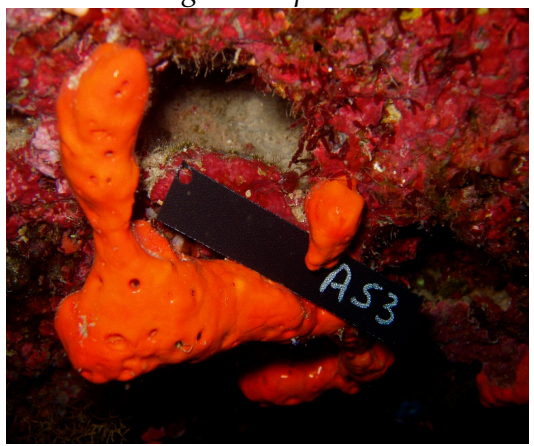

Agelas sp.

Figure 1. Photos of Agelas sponges provided by professor Crews.

\section{Natural Products from Agelas Genus}

The chemical diversity of natural products is determined by the biological diversity of organisms. To date, 291 secondary metabolites (1-291) have been isolated and characterized from the marine sponge Agelas spp. (Table 1). These chemicals were introduced and assorted as follows according to their biological sources. 


\subsection{Agelas axifera}

Three new alkaloids, named axistatins 1 (1), 2 (2), and 3 (3) (Figure 2), were isolated and characterized from Agelas axifera collected in the Republic of Palau and found to exhibit inhibitory effects on cancer cell lines, including P388, BXPC-3, MCF-7, SF-268, NCI-H460, KM20L2 and DU-145. The exquisitely sensitive Gram-negative pathogen Neisseria gonorrheae and the opportunistic fungus Cryptococcus neoformans were inhibited by 1-3 with MIC values of $1-8,2-4$, and $8 \mu \mathrm{g} / \mathrm{mL}$, and $1-4,2$, and $8-16 \mu \mathrm{g} / \mathrm{mL}$, respectively. Furthermore, these compounds had antimicrobial effect on Gram-positive bacteria, including Staphylococcus aureus, Streptococcus pneumoniae, Enterococcus faecalis and Micrococcus luteus [4].<smiles>CNc1ncnc(N)c1N(C)C/C=C1/CC[C@]2(C)CCC=C(C)[C@@]1(C)CCC2C</smiles>

1<smiles>CNc1ncnc(N)c1N(C)C/C=C1/CC[C@H]2C3CCC=C(C)[C@@]3(C)CC[C@@H]2C1</smiles>

2

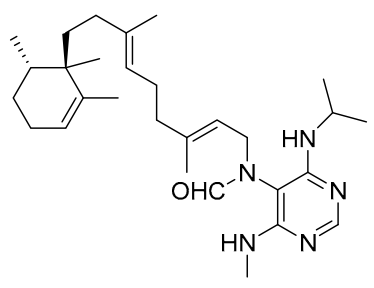

3

Figure 2. Chemical structures of compounds 1-3.

\subsection{Agelas cerebrum}

Marine sponge Agelas cerebrum was classified as a new species in 2001 [5]. Chemical investigation of Caribbean specimen A. cerebrum led to the isolation of three brominated compounds, 5-bromopyrrole-2carboxylic acid (4), 4-bromopyrrole-2-carboxylic acid (5) and 3,4-bromopyrrole-2-carboxylic acid (6) (Figure 3) [6]. Biological tests indicated that these isolates had strong cytotoxic activities in vitro against human tumor cell lines at $\geq 1 \mathrm{mg} / \mathrm{mL}$, including A549, HT29 and MDA-MB-231.<smiles>[R]c1[nH]c(C(=O)O)c([R])c1[R]</smiles>

$$
\begin{aligned}
& \text { 4: } \mathrm{R}_{1}=\mathrm{H}, \mathrm{R}_{2}=\mathrm{H}, \mathrm{R}_{3}=\mathrm{Br} \\
& \text { 5: } \mathrm{R}_{1}=\mathrm{H}, \mathrm{R}_{2}=\mathrm{Br}, \mathrm{R}_{3}=\mathrm{H} \\
& \text { 6: } \mathrm{R}_{1}=\mathrm{Br}, \mathrm{R}_{2}=\mathrm{Br}, \mathrm{R}_{3}=\mathrm{H} .
\end{aligned}
$$

Figure 3. Chemical structures of compounds 4-6.

\subsection{Agelas ceylonica}

Only one case of chemical study on Agelas ceylonica has been reported [7]. The specimen of A. ceylonica collected from India Mandapam coast was found to produce one methyl ester hanishin (7) (Figure 4), which has been previously found in the marine sponge Homaxinella sp. [8].

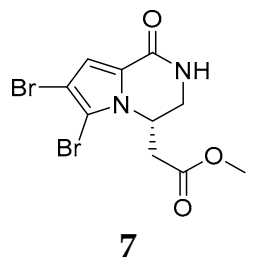

Figure 4. Chemical structures of compounds 7. 


\subsection{Agelas citrina}

The Caribbean specimen of Agelas citrina was firstly found to yield three new diterpene alkaloids, (-)-agelasidine E (8), (-)-agelasidine F (9) and agelasine N (10) [9]. Latter chemical investigation showed that this sponge also produces four new pyrrole-imidazole alkaloids, citrinamines A-D (11-14), and one bromopyrrole alkaloid $N$-methylagelongine (15) (Figure 5) [10]. Compounds 12-14 had antimicrobial activities whereas no inhibitory effect on cell proliferation of mouse fibroblasts was found for 11-14.

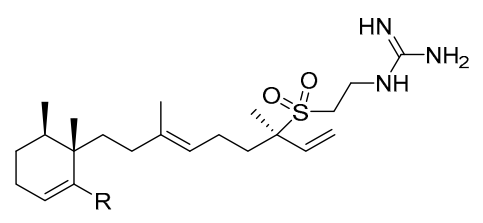

8: $\mathrm{R}=\mathrm{CH}_{2} \mathrm{OH}$

9: $\mathrm{R}=\mathrm{CHO}$

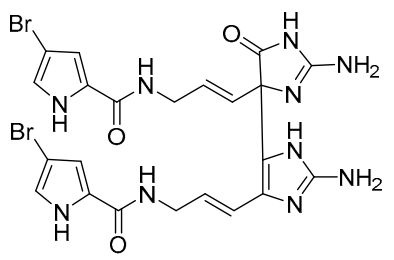

11

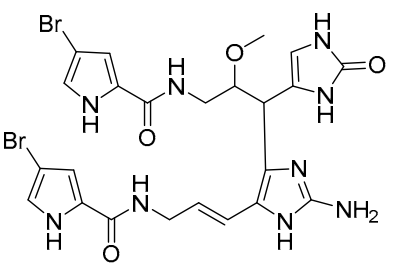

13

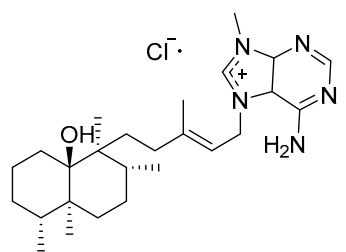

10<smiles>NC1=NC(/C=C/CNC(=O)c2cc(Br)c[nH]2)(c2[nH]c(N)nc2/C=C/CNC(=O)c2cc(Br)c[nH]2)/C(=N\CCS(=O)(=O)O)N1</smiles>

12

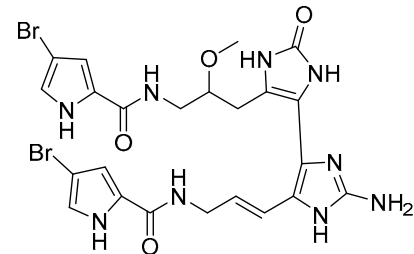

14<smiles>Cn1cc(Br)cc1C(=O)OCC[n+]1cccc(C(=O)[O-])c1</smiles>

15

Figure 5. Chemical structures of compounds 8-15.

\subsection{Agelas clathrodes}

Marine sponge Agelas clathrodes was the excellent producer of secondary metabolites, including glycosphingolipid derivatives (GSLs) and alkaloids. Clarhamnoside (16), containing an unusual L-rhamnose unit in the sugar head, was the first rhamnosylated $\alpha$-galactosylceramide from $A$. clathrodes collected along the coast of Grand Bahamas Island (Sweetings Cay) [11]. The Caribbean sponge A. clathrodes could metabolize clathrosides A-C (17-19) and isoclathrosides A-C (20-22), which, respectively, belonged to two families of different glycolipids [12]. Compound $\mathbf{2 3}$ was also isolated from the Caribbean specimen (Figure 6) [13]. It was noted that all the GSLs from A. clathrodes were actually elucidated as mixtures of homologs, which play an important role in therapeutic immunomodulation.

Six alkaloids, (-)-agelasidine A (24), (-)-agelasidine C (25), (-)-agelasidine D (26), clathramide A (27), clathramide B (28) and clathrodin (29), were detected in the Caribbean sponge A. clathrodes (Figure 7). Bioassay results suggested that compound 24 possessed inhibitory effect on Staphilococcus aureus but no effect on fungi, while $\mathbf{2 5}$ and $\mathbf{2 6}$ were shown to have antimicrobial activities against S. aureus, Klebsiella pneumoniae and Proteus vulgaris [14]. In vitro cytotoxic test indicated that 
25 and 26 significantly inhibited the growth of CHO-K1 cells with the $\mathrm{ED}_{50}$ values of 5.70 and $2.21 \mu \mathrm{g} / \mathrm{mL}$, respectively. Compound 26 also possessed the inhibition against the growth of $E$. coli and Hafnia alvei [15], while $\mathbf{2 7}$ and $\mathbf{2 8}$ had a moderate antifungal activity against Aspergillus niger [16]. Interestingly, compound 29 contained a nonbrominated pyrrole and a guanidine moiety [17]. One specimen of $A$. clathrodes from the South China Sea was shown to produce an ionic compound (30), which had weak cytotoxicity against cancer cell lines A549 and SGC7901 with $\mathrm{IC}_{50}$ values of 26.5 and $22.7 \mu \mathrm{g} / \mathrm{mL}$, respectively [18]. Four brominated compounds, dispacamides A-D (31-34) (Figure 7), were detected not only in A. clathrodes, but also in A. conifera, A. dispar and A. longissima, and exhibited antihistamine activity $[19,20]$.
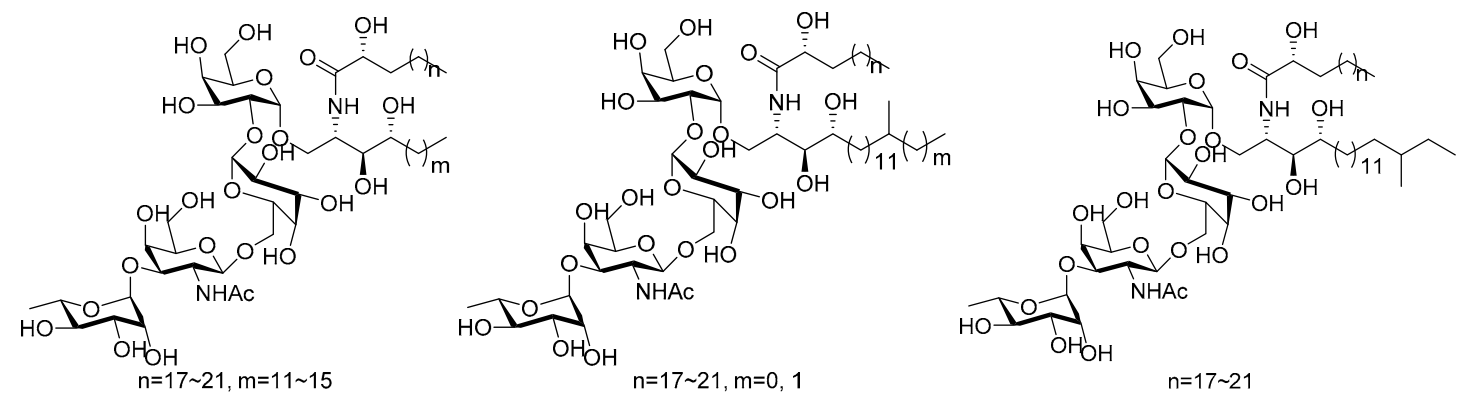

16

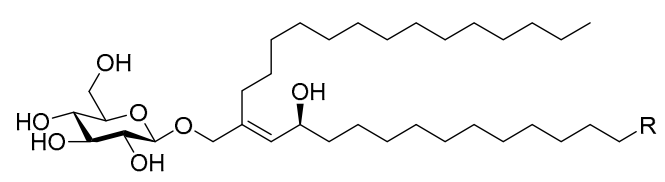

17: $\mathrm{R}=\mathrm{CH}_{2} \mathrm{CH}_{2} \mathrm{CH}_{3}$

18: $\mathrm{R}=\mathrm{H}\left(\mathrm{CH}_{3}\right) \mathrm{CH}_{2} \mathrm{CH}_{3}$

19: $\mathrm{R}=\mathrm{CH}_{2} \mathrm{CH}\left(\mathrm{CH}_{3}\right)_{2}$

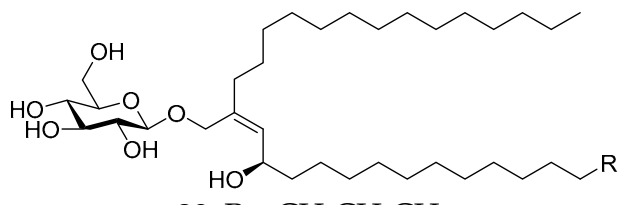

20: $\mathrm{R}=\mathrm{CH}_{2} \mathrm{CH}_{2} \mathrm{CH}_{3}$

21: $\mathrm{R}=\mathrm{CH}\left(\mathrm{CH}_{3}\right) \mathrm{CH}_{2} \mathrm{CH}_{3}$

22: $\mathrm{R}=\mathrm{CH}_{2} \mathrm{CH}\left(\mathrm{CH}_{3}\right)_{2}$

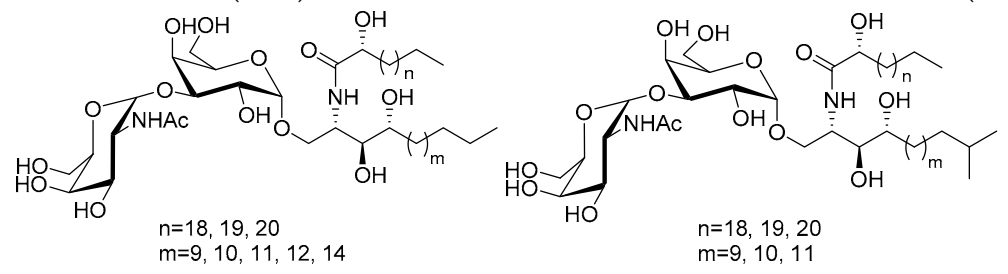

23

Figure 6. Chemical structures of compounds 16-23.

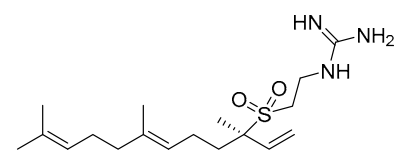

24<smiles>Nc1ncc(C=CCNC(=O)c2ccc[nH]2)[nH]1</smiles>

29<smiles>[R]C/C(=C\C(=O)S(=O)(=O)CCNC(=N)N)CC/C=C(\C)CCC1C(C)=CCC[C@H]1C</smiles>

25: $\mathrm{R}=\mathrm{H}$

26: $\mathrm{R}=\mathrm{OH}$<smiles>[R2]C(C[C@]1([Z20])CN=CN1C)NC(=O)c1cc(Br)c[nH]1</smiles>

27: $\mathrm{R}_{1}=\mathrm{H}, \mathrm{R}_{2}=\mathrm{COOH}$

28: $\mathrm{R}_{1}=\mathrm{COOH}, \mathrm{R}_{2}=\mathrm{H}$<smiles>[X]CC(n1ccc(=O)[nH]c1=O)n1ccc(=O)[nH]c1=O</smiles>

30<smiles>[R]c1[nH]c(C(=O)NCC/C=C2\NC(N)=NC2=O)cc1Br</smiles>

31: $\mathrm{R}=\mathrm{Br}$

32: $\mathrm{R}=\mathrm{H}$<smiles>[R]c1[nH]c(C(=O)NCC(O)/C=C2\NC(N)=NC2=O)cc1Br</smiles>

33: $\mathrm{R}=\mathrm{Br}$

34: $\mathrm{R}=\mathrm{H}$

Figure 7. Chemical structures of compounds 24-34. 


\subsection{Agelas conifera}

Chemical study of two specimens of Agelas conifera from the Florida Keys and Belize led to the isolation of two new dimeric bromopyrrole alkaloids, bromosceptrin (35) and debromosceptrin (36), respectively [21,22]. Seven new bromopyrrole metabolites (37-43) were firstly purified from the Caribbean sponge A. conifera [23], but the detailed structure elucidation of ageliferin (41), bromoageferin (42) and dibromoageliferin (43) were established by Kobayashi and his co-workers [24]. Bioassay results indicated that compounds $37,41,42$ and 43 possessed biological activities against Bacillus subtilis at $10 \mu \mathrm{g} /$ disk and 41 and 42 could inhibit the growth of E. coli at $10 \mu \mathrm{g} /$ disk. Using new protein-guided methods by its affinity to proteins within tumor cell proteomes, one unique polyhydroxybutyrated $\beta$-GSL coniferoside (44), was detected in A. conifera derived from Puerto Rico as well as another GSL derivative (45) (Figure 8) [25,26].<smiles></smiles>

35<smiles>[R]c1[nH]c(C(=O)NCC2[C@@H](CNC(=O)c3cc(Br)c([R])[nH]3)Cc3[nH]c(N)nc3[C@@H]2c2cnc(N)[nH]2)cc1Br</smiles>

41: $\mathrm{R}_{1}=\mathrm{H}, \mathrm{R}_{2}=\mathrm{H}$

42: $\mathrm{R}_{1}=\mathrm{Br}, \mathrm{R}_{2}=\mathrm{H}$

43: $\mathrm{R}_{1}=\mathrm{Br}, \mathrm{R}_{2}=\mathrm{Br}$

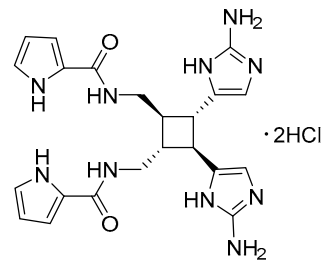

36

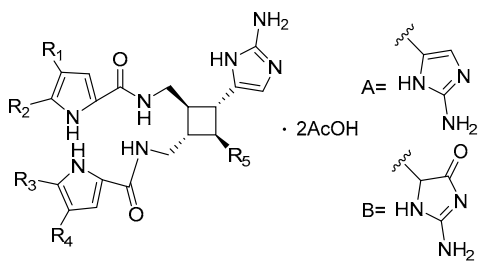

$\mathrm{R}_{1} \mathrm{R}_{2} \mathrm{R}_{3} \mathrm{R}_{4} \mathrm{R}_{5}$

37: $\mathrm{Br} \mathrm{H} \mathrm{H} \mathrm{H} \mathrm{A}$

38: $\mathrm{Br} \mathrm{Br} \mathrm{Br} \mathrm{Br} \mathrm{A}$

39: $\mathrm{H} \mathrm{H} \mathrm{H} \mathrm{Br} \mathrm{B}$

40: $\mathrm{Br} \mathrm{H} \mathrm{H} \mathrm{Br} \mathrm{B}$

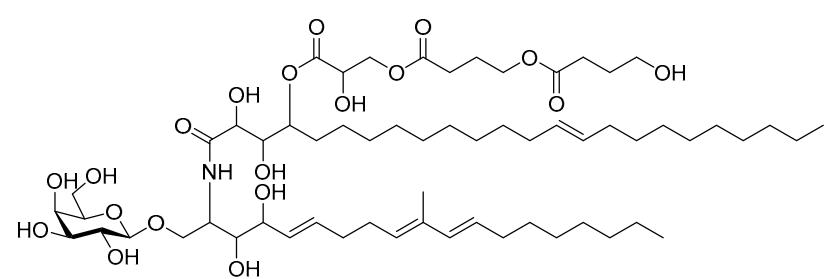

44

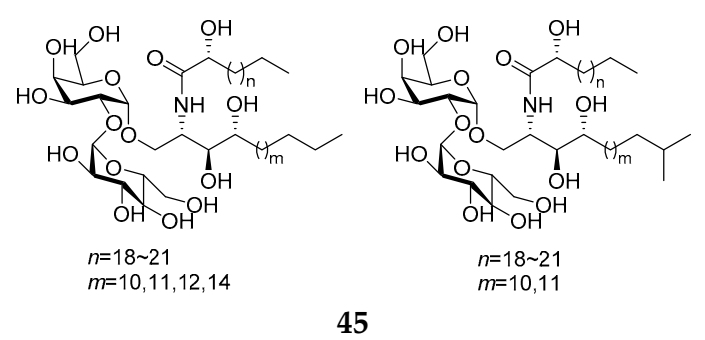

Figure 8. Chemical structures of compounds 35-45.

\subsection{Agelas dendromorpha}

Natural product analysis of the marine sponge Agelas dendromorpha revealed three novel agelastatins (46-48) with pyrrole-2-imidazole structure. Agelastatin A (46) was obtained from the Axinellid specimen grown in the Coral Sea and had strong cytotoxicity [27]. Agelastatins E (47) and F (48) (Figure 9) purified from the New Caledonian A. dendromorpha were shown to exhibit weak cytotoxicity against the $\mathrm{KB}$ cell line at $30 \mu \mathrm{M}$ [28]. 
<smiles>CN1C(=O)N[C@]2(C)C3NC(=O)c4ccc(Br)n4C3C[C@]12O</smiles>

46<smiles>[R]O[C@]12C[C@H]3[C@@H](NC(=O)c4cc([R])c(Br)n43)[C@@H]1NC(=O)N2[R]</smiles>

47: $\mathrm{R}_{1}=\mathrm{H}, \mathrm{R}_{2}=\mathrm{CH}_{3}, \mathrm{R}_{3}=\mathrm{CH}_{3}$

48: $\mathrm{R}_{1}=\mathrm{Br}, \mathrm{R}_{2}=\mathrm{H}, \mathrm{R}_{3}=\mathrm{H}$

Figure 9. Chemical structures of compounds 46-48.

\subsection{Agelas dispar}

It is notable that Caribbean Agelas dispar harbors a distinct biogeographical bromination trend. Five compounds containing bromine, dispyrin (49), dibromoagelaspongin methyl ether (50), longamide B (51), clathramides C (52) and D (53), have been found in the Caribbean sponge A. dispar [29,30]. Only compound $\mathbf{5 1}$ had moderate anti-bacterial activities against $B$. subtilis and $S$. aureus with MIC values of about $50 \mu \mathrm{g} / \mathrm{mL}$. The GSL derivative (54) and betaine alkaloids (55-57) were detected in the Caribbean $A$. dispar [31,32]. Antibacterial tests indicated that compounds $\mathbf{5 5}$ and $\mathbf{5 6}$ had the inhibitory activities against B. subtilis and $S$. aureus with MIC values ranging from 2.5 to $8.0 \mu \mathrm{g} / \mathrm{mL}$ [32]. The first quaternary derivative of adenine in nature, agelasine (58) (Figure 10), was also found in A. dispar [33].

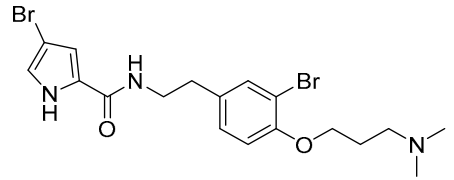

49

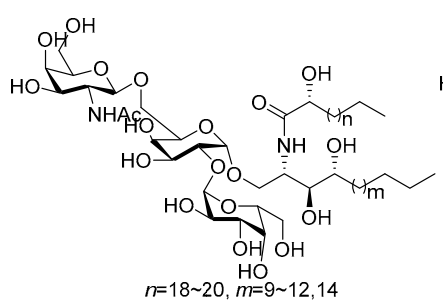

54

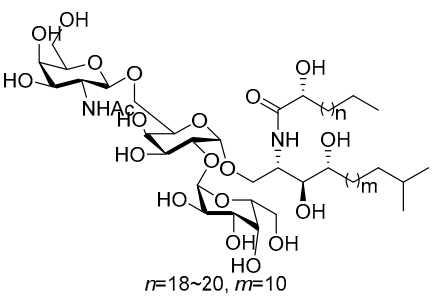

50<smiles>O=C(O)CC1CNC(=O)c2cc(Br)c(Br)n21</smiles>

51

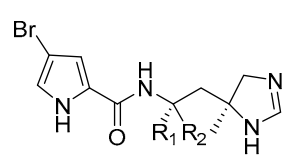

52: $\mathrm{R}_{1}=\mathrm{H}, \mathrm{R}_{2}=\mathrm{COOH}$

53: $\mathrm{R}_{1}=\mathrm{COOH}, \mathrm{R}_{2}=\mathrm{H}$<smiles>Cn1cc(CC(=O)O)n(C)c1=N</smiles>

55<smiles>C=CCn1cnc2c(N)ncnc21</smiles>

58<smiles></smiles>

56<smiles></smiles>

57

Figure 10. Chemical structures of compounds $49-58$.

\subsection{Agelas gracilis}

Bioassay-guided fractionation of the crude extract of the deep-sea sponge Agelas gracilis collected in southern Japan afforded three novel antiprotozoan compounds, gracilioethers A-C (59-61) (Figure 11) [34]. Antimalarial tests showed that these metabolites possessed inhibitory effects on Plasmodium falciparum with $\mathrm{IC}_{50}$ values of $0.5-10 \mu \mathrm{g} / \mathrm{mL}$.

\subsection{Agelas linnaei}

Eleven novel brominated pyrrole derivatives (62-72) (Figure 12) were purified from the Indonesian sponge Agelas linnaei and compounds 66-69 had prominent activities against the murine L1578Y mouse lymphoma cell line with $\mathrm{IC}_{50}$ values of $9.55,9.25,16.76$ and $13.06 \mu \mathrm{M}$, respectively [35]. 


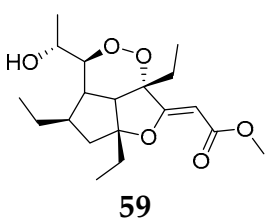

59

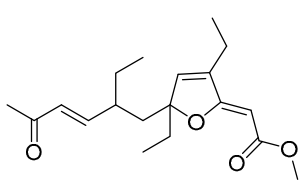

60

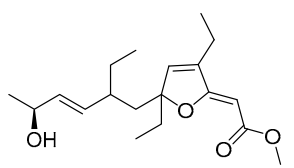

61

Figure 11. Chemical structures of compounds 59-61.<smiles></smiles>

62<smiles>CC(=O)C(O)(CCCNC(=O)c1cc(Br)c(Br)n1C)CC(=O)O</smiles>

65<smiles>[R]c1cc(CCN(C)C)ccc1OCCCNC(=O)c1cc(Br)c([R])[nH]1</smiles>

66: $\mathrm{R}_{1}=\mathrm{H}, \mathrm{R}_{2}=\mathrm{Br}$

67: $\mathrm{R}_{1}=\mathrm{H}, \mathrm{R}_{2}=\mathrm{I}$

68: $\mathrm{R}_{1}=\mathrm{Br}, \mathrm{R}_{2}=\mathrm{Br}$

69: $\mathrm{R}_{1}=\mathrm{Br}, \mathrm{R}_{2}=\mathrm{I}$<smiles>Cn1c(Br)cc(Br)c1C(=O)NCCCC(=O)O</smiles>

63

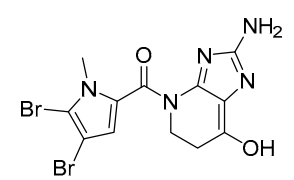

64

Figure 12. Chemical structures of compounds 62-72.

\subsection{Agelas longissima}

Five alkaloids (73-77) (Figure 13) have been isolated from Agelas longissima specimens, all of which were collected from the Caribbean Sea. Agelongine (73) contained a pyridinium ring instead of the commonly found imidazole nucleus in Agelas alkaloids and was shown to be specific to inhibit the agonist 5-hydroxytryptamine (5-HT) [36]. Compound 75 was unique for its unusual pyrrolopiperazine nucleus [37]. Two new GSL analogs (76 and 77) were also found in the Caribbean A. longissima [38,39].

\subsection{Agelas mauritiana}

Agelas mauritiana is one of the most fruitful producers of secondary metabolites among all Agelas species. Thirty-five compounds (78-112) have been isolated and identified from A. mauritiana, including terpenoids, pyrrole derivatives, GSLs, carotenoids and other alkaloids. Specimens of A. mauritiana collected from the South China Sea were found to metabolize eight terpenoids (78-85) [40,41]. Compound 79 possessed inhibitory effects on $S$. aureus with $\mathrm{MIC}_{90}$ value of 1-8 $\mu \mathrm{g} / \mathrm{mL}$ and activities against PC9, A549, HepG2, MCF-7, and U937 cell lines with IC $_{50}$ values of 4.49-14.41 $\mu$ M. Compound $\mathbf{8 4}$ possessed activities against C. neoformans, S. aureus, methicillin-resistant $S$. aureus and Leishmania donovani with $\mathrm{IC}_{50} / \mathrm{MIC}$ values of 4.96/10.00, 7.21/10.00, 9.20/20.00 and 28.55/33.19 $\mu \mathrm{g} / \mathrm{mL}$, respectively. Agelasimines A (86) and B (87) and an unusual purino-diterpene (88) were purified from Eniwetak $A$. mauritiana and 86 and $\mathbf{8 7}$ had inhibitory effect on L1210 leukemia with ED 50 values of 2.1 and $3.9 \mathrm{nM}$, respectively. From Pohnpei-derived A. mauritiana, epi-agelasine C (89) was isolated and shown to have no activity against $S$. aureus, Vibrio costicola, E. coli and B. subtilis [42-44]. Chemical analysis of one specimen of $A$. auritiana collected from the Solomon Islands afforded agelasines J (90), K (91) and L (92) (Figure 14), which exhibited moderate activities against P. falciparum and low cytotoxicity on MCF-7 cells [45]. 


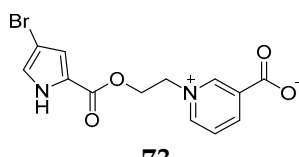

73<smiles>O=C1NC[C@@H](O)n2c1cc(Br)c2Br</smiles>

75

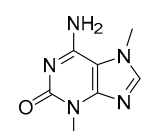

74

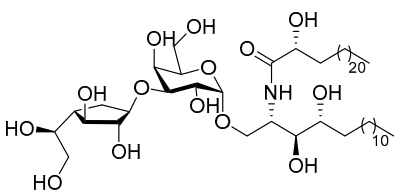

76

$$
\text { (n) }
$$

Figure 13. Chemical structures of compounds 73-77.

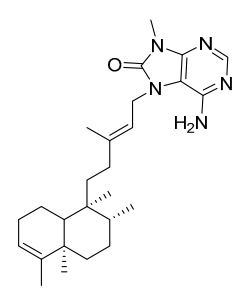

78

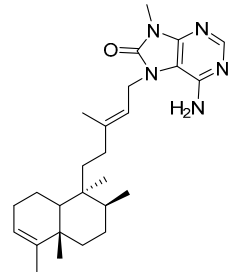

81

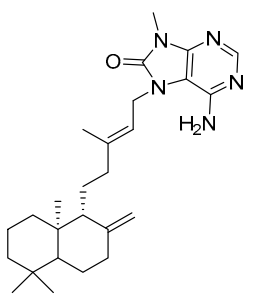

83

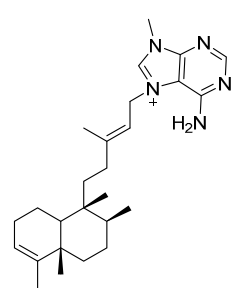

79

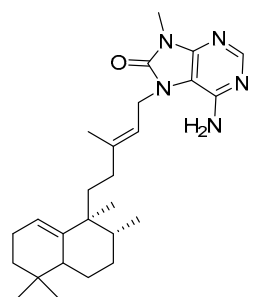

80

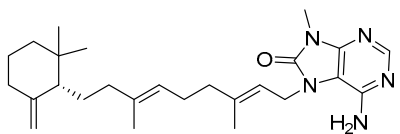

82

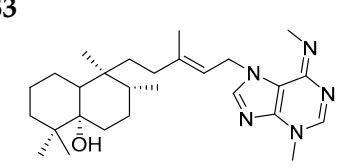

86

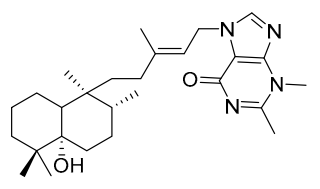

88

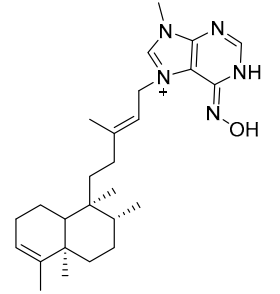

84
85

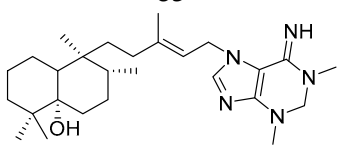

87

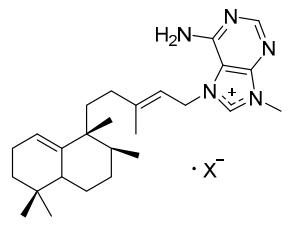

89

Figure 14. Cont. 


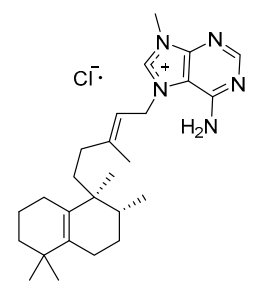

90

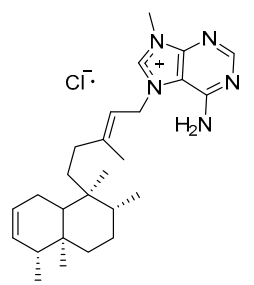

91

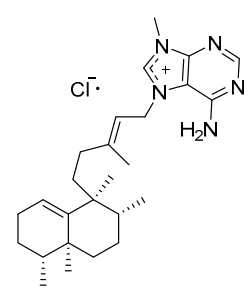

92

Figure 14. Chemical structures of compounds 78-92.

The same species of $A$. mauritiana grown in different places were found to produce different pyrrole derivatives, such as debromodispacamides B (93) and D (94) from Solomon Island specimen [46], 4-bromo- $\mathrm{N}$-(butoxymethyl)-1H-pyrrole-2-carboxamide (95) from the South China Sea [41], 5-debromomidpacamide (96) from Enewetak Atoll [47], mauritamide A (97) from Fiji [48] and mauritiamine (98) from Hachijo-jima Island [49]. Compound 98 exhibited inhibitory effect on larval metamorphosis of the barnacle Balanus amphitrite with $\mathrm{ED}_{50}$ value of $15 \mu \mathrm{g} / \mathrm{mL}$ and moderate antibacterial activity against Flavobacterium marinotypicum with the inhibition zone of $10 \mathrm{~mm}$ at $10 \mu \mathrm{g} /$ disk. Interestingly, the Pacific sponge A. mauritiana was found to metabolize other pyrroles, including debromokeramadine (99), benzosceptrin A (100), nagelamide S (101) and nagelamide T (102) (Figure 15) [50,51].<smiles>[R]C(/C=C1\N=C(N)NC1=O)=C\CNC(=O)c1ccc[nH]1</smiles>

93: $\mathrm{R}=\mathrm{H}$

94: $\mathrm{R}=\mathrm{OH}$<smiles>CN1C(=O)NC(CCCCC(=O)c2cc(Br)cn2C)C1=O</smiles>

96<smiles></smiles>

98<smiles></smiles>

100<smiles>CCCCOCNC(=O)c1cc(Br)c[nH]1</smiles>

95<smiles>CO[Si](C)(O)OCC[C@@]1(CCCNC(=O)c2cc(Br)c(Br)n2C)C(=O)N[C@H](N)N1C</smiles>

97<smiles>Cn1c(/C=C\CNC(=O)c2ccc[nH]2)cnc1N</smiles>

99

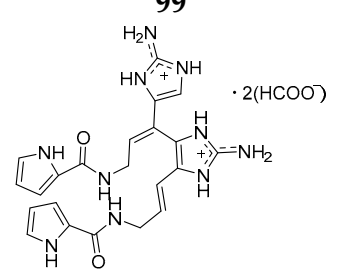

101

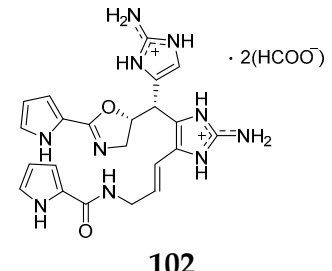

Figure 15. Chemical structures of compounds 93-102. 
Agelasphins (103-110) from the Okinawan A. mauritiana were the first example of galactosylceramides containing an $\alpha$-galactosyl linkage [52,53]. These compounds exhibited high activity with the relative tumor proliferation rate (T/C) ranging from $160 \%$ to $190 \%$ and $200-400 \%$ relative ${ }^{3} \mathrm{H}-\mathrm{TdR}$ incorporation at $<\mathrm{l} \mu \mathrm{g} / \mathrm{mL}$. But no activity was observed against B16 melanoma cells at $20 \mu \mathrm{g} / \mathrm{mL}$. Two natural carotenoids, isotedanin (111) and isoclathriaxanthin (112) (Figure 16), were also detected in the specimen of A. mauritiana from Kagoshima [54].

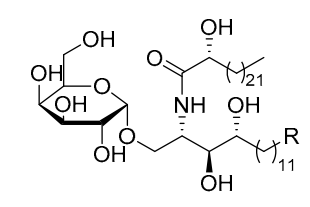

103: $\mathrm{R}=\mathrm{CH}_{3}$

104: $\mathrm{R}=\mathrm{CH}_{2} \mathrm{CH}_{3}$

105: $\mathrm{R}=\mathrm{CH}\left(\mathrm{CH}_{3}\right)_{2}$

106: $\mathrm{R}=\mathrm{CH}\left(\mathrm{CH}_{3}\right) \mathrm{C}_{2} \mathrm{H}_{5}$

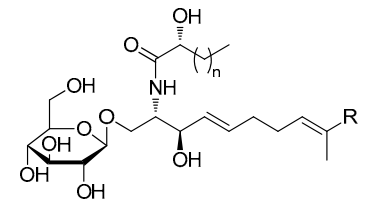

107: $n=21, \mathrm{R}=\curvearrowright\left(\mathrm{CH}_{2}\right)_{6} \mathrm{CH}_{3}$

108: $n=22, \mathrm{R}=\leadsto\left(\mathrm{CH}_{2}\right)_{6} \mathrm{CH}_{3}$

109: $n=13, \mathrm{R}=-\left(\mathrm{CH}_{2}\right)_{8} \mathrm{CH}_{3}$

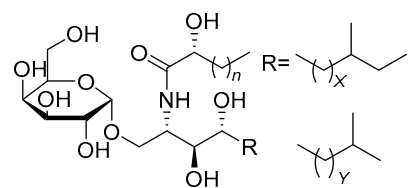

110: $n=20, Y=10$ and/or $Z=11$; $n=21, Y=9$ and/or $Z=10$<smiles>CC(C)=C(C)/C=C/C(C)=C/C=C/C(C)=C/C=C/C=C(C)/C=C/C=C(C)/C=C/c1c(C)ccc(C)c1C</smiles>

111<smiles>CC(C)=C/C=C/C=C(C)/C=C/C(C)=C/C=C/C(C)=C/C=C/C=C(C)/C=C/c1c(C)ccc(C)c1C</smiles>

112

Figure 16. Chemical structures of compounds 103-112.

\subsection{Agelas nakamurai}

Thirty-three chemicals have been characterized from Agelas nakamurai, including 16 terpenoids and 17 pyrrole alkaloids. The Okinawan A. nakamurai seems to occupy the majority of terpenoid compounds, including agelasidines B (113) and C (114) [55], nakamurols A-D (115-118) [56], 2-oxoagelasiines A (119) and F (120), 10-hydro-9-hydroxyagelasine F (121) [57], agelasines E (122) and F (123) [58]. Compounds 113 and 114 were found to have inhibitory effects on the growth of $S$. aureus at $3.3 \mu \mathrm{g} / \mathrm{mL}$ and on contractile responses of smooth muscles. Compounds 119 and 120 showed markedly reduced activity against Mycobacterium smegmatis. The Indonesian A. nakamurai was found to yield two novel diterpenes, (-)-agelasine D (124) and (-)-ageloxime D (125). Antibacterial assay revealed 124 could inhibit the growth of Staphylococcus epidermidis with a MIC value $<0.0877 \mu \mathrm{M}$ [35]. Isoagelasine C (126) and isoagelasidine B (127) were isolated from specimen of the South China Sea and possessed weak cytotoxicities against HL-60, K562 and HCT-116 cell lines with $\mathrm{IC}_{50}$ values ranging from 18.4 to $39.2 \mu \mathrm{M}$ [59]. A new diterpene (128) (Figure 17) with a 9-methyladenum moiety produced by the Papua New Guinean A. nakamurai Hoshino was shown to be inactive against HIV-1 integrase, E. coli and Pseudomonas aeruginosa at $12.5 \mu \mathrm{g} / \mathrm{mL}$ [60].

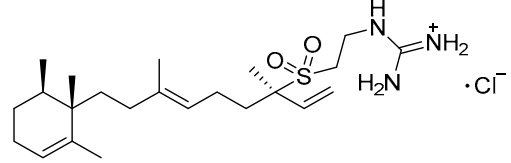

113<smiles>C=CC1(O)CCC2C(=O)CCC3(C)CC21CCCC3C</smiles>

115

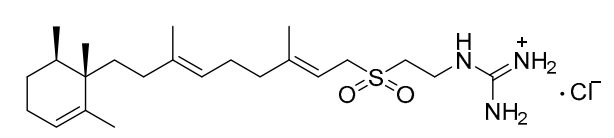

114

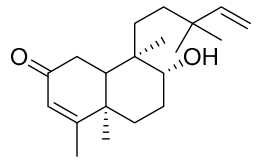

116

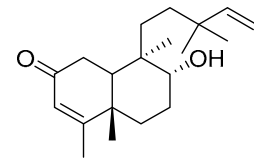

117

Figure 17. Cont. 


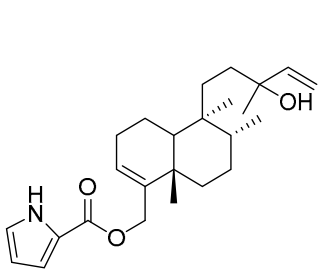

118

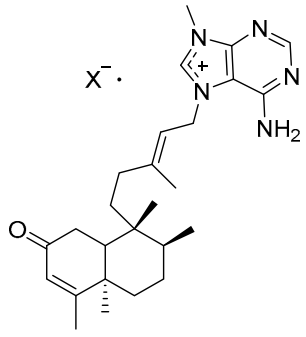

119

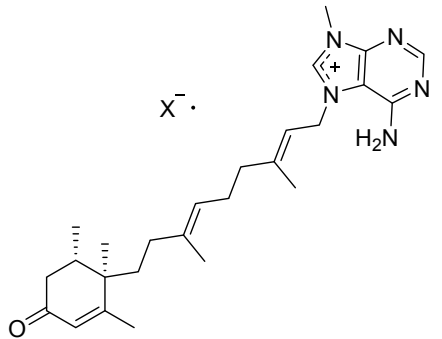

120

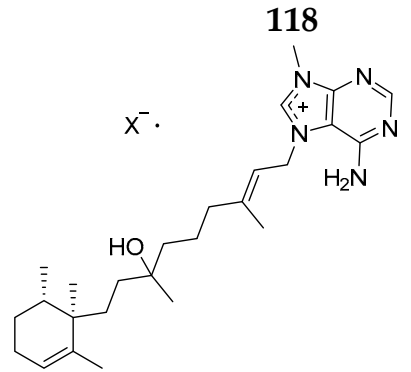

121

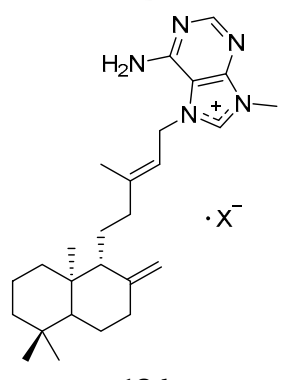

124

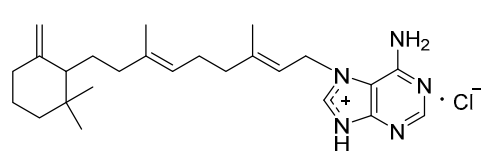

122

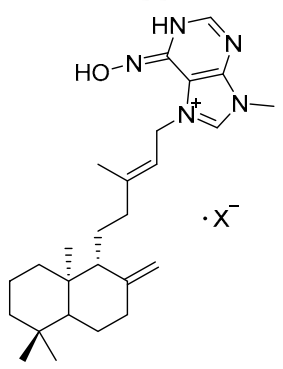

125<smiles>CC1=CCC[C@H](C)C1C/C=C(\C)CC/C=C(\C)CCn1cnc2nc(Cl)nc(N)c21</smiles>

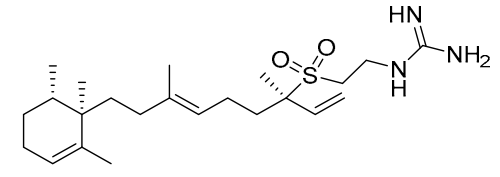

127

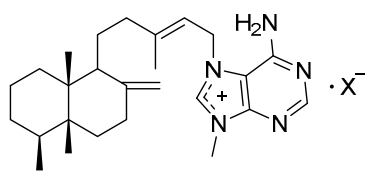

128

Figure 17. Chemical structures of compounds 113-128.

Five non-brominated pyrrole derivatives, nakamurines A-E (129-133), were purified from the South China Sea A. nakamurai $[59,61]$. Bioassay results showed that compound $\mathbf{1 3 0}$ had weak inhibition against Candida albicans with a MIC value of $60 \mu \mathrm{g} / \mathrm{mL}$ [61]. Bromopyrrole alkaloid was one of the most common secondary metabolites from marine sponges [62]. Two bromopyrrole alkaloids (134 and 135) were firstly isolated from the Papua New Guinean A. nakamurai in 1998 [60]. Ageladine A (136) containing 2-aminoimidazolopyridine was shown to have inhibitory effects on Matrix metalloproteinases-1, $-2,-8,-9,-12$ and -13 with $\mathrm{IC}_{50}$ values of $1.2,2.0,0.39,0.79,0.33$, and $0.47 \mu \mathrm{g} / \mathrm{mL}$, respectively [63]. Chemical investigation of the Indonesia A. nakamurai afforded longamide C (137) [35]. Nakamuric acid (138) and its methyl ester (139) were characterized from the Indopacific specimen and shown to be active against $B$. subtilis [64]. The Okinawan $A$. nakamurai was found to produce six brominated pyrrole derivatives, slagenins A-C (140-142) and mukanadins A-C (143-145) (Figure 18), of which 141 and 142 showed inhibitory effect on murine leukemia L1210 cells in vitro with IC $_{50}$ values of 7.5 and $7.0 \mu \mathrm{g} / \mathrm{mL}$, respectively $[65,66]$. 


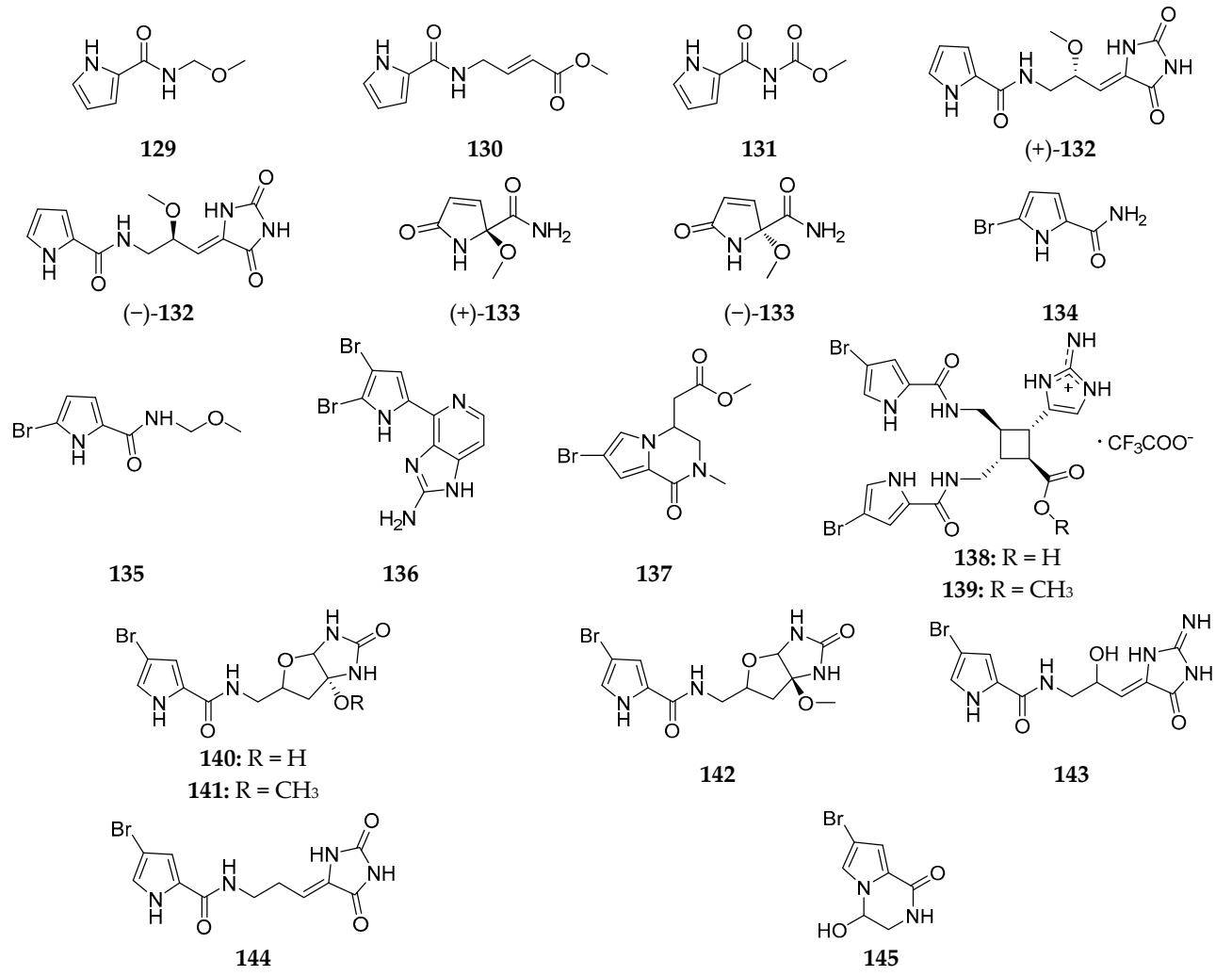

Figure 18. Chemical structures of compounds 129-145.

\subsection{Agelas nemoechinata}

Nemoechines A-D (146-149) and nemoechioxide A (150) were obtained from the sponge Agelas aff. nemoechinata collected from the South China Sea. Compounds 146-148 had enantiomeric configurations and $\mathbf{1 4 6}$ had an unusual cyclopentene-fused imidazole ring system. Bioassay results suggested that only 149 had cytotoxicity against HL-60 cell lines with an $\mathrm{IC}_{50}$ value of $9.9 \mu \mathrm{M}$ [67]. Two new nemoechine members, nemoechines F (151) and G (152) possessing $N$-methyladenine, were purified from the South China Sea-derived A. nemoechinata. Compound $\mathbf{1 5 2}$ had weak toxicity against Jurkat cell line with an $\mathrm{IC}_{50}$ value of $17.1 \mu \mathrm{M}$ [68]. Oxysceptrin (153) (Figure 19) derived from the Okinawan A. nemoechinata was a potent actomyosin ATPase activator [69].<smiles>COC12CC(O)C(NC(=O)c3ccc[nH]3)C1NC(=O)N2</smiles>

$(+)-146$

$(-)-146$<smiles>CCCCC(C)CC12OC1(CC)C2(O)CC=CC(=O)OC</smiles>

150

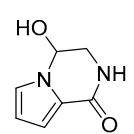

(+)-147

$(-)-147$

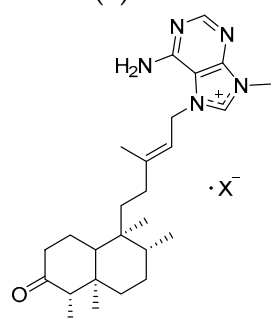

151

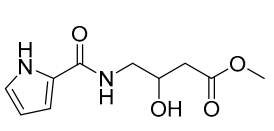

(+)-148

$(-)-148$

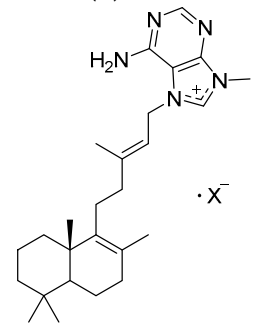

152<smiles>CC1=CCCC2[C@@H](CC/C(C)=C/Cn3c(=O)n(C)c4ncnc(N)c43)C(C)CC[C@@H]12</smiles>

149

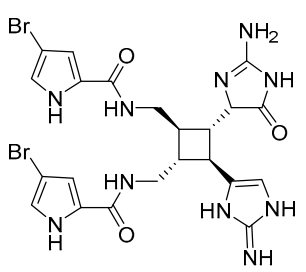

153

Figure 19. Chemical structures of compounds 146-153. 


\subsection{Agelas oroides}

Thirty-six secondary metabolites (154-189) (Figure 20) have been isolated from the marine sponge Agelas oroides, including pyrrole derivatives, sterols and fatty acids. Chemical investigation of $A$. oroides from the Great Barrier Reef afforded three fistularin-3 derivatives, agelorin A (154), agelorin B (155) and 11-epi-fistularin-3 (156). These metabolites exhibited antimicrobial activities against $B$. subtilis and $M$. luteus and 156 had moderate cytotoxicity against breast cancer cells [70]. Later on, two new naturally occurring pyrrole derivatives (157 and 158) and 2,4,6,6-tetramethyl-3(6H)-pyridone (159) were obtained from the same specimen [71,72]. Mediterranean $A$. oroides was shown to produce four novel compounds, cyclooroidin (160), taurodispacamide A (161), monobromoagelaspongin (162) and (-)-equinobetaine B (163), of which 161 displayed strong antihistaminic activity [73,74]. Five bromopyrrole alkaloids (164-168) and fifteen sterols (169-183) were detected in the sponge A. oroides collected in the Bay of Naples [75,76]. Interestingly, one imidazole compound (184), taurine (185) and some fatty acids (186-189) were also found in the Northern Aegean Sea-derived specimen [77].

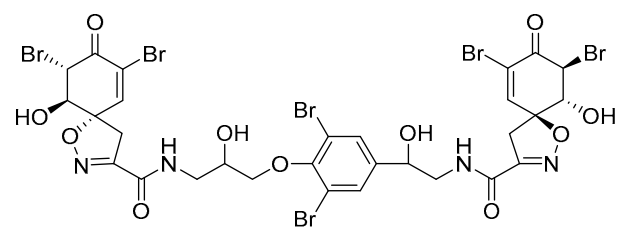

154

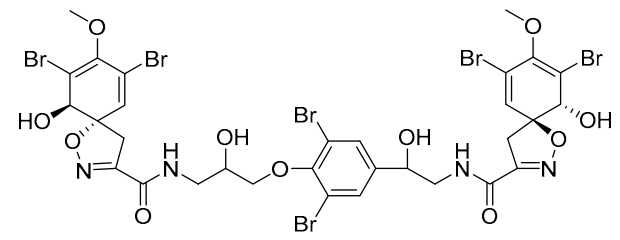

156<smiles>Nc1nnc(C[C@H]2CNC(=O)c3cc(Br)c(Br)n32)[nH]1</smiles>

160

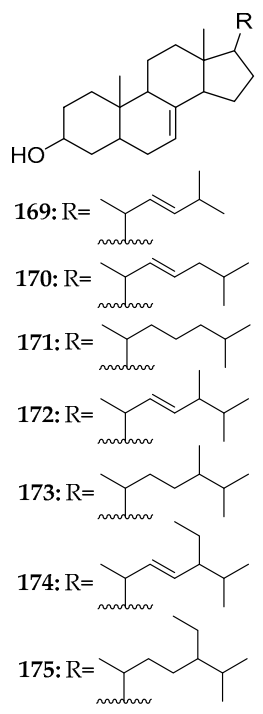

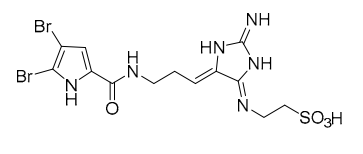

161

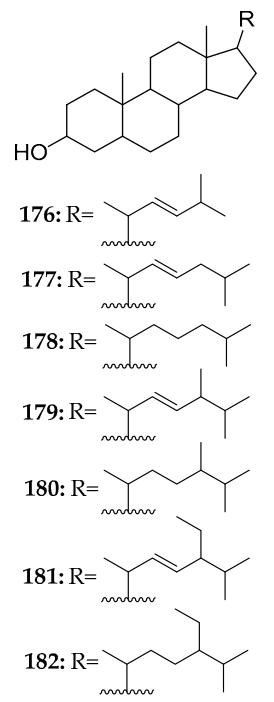

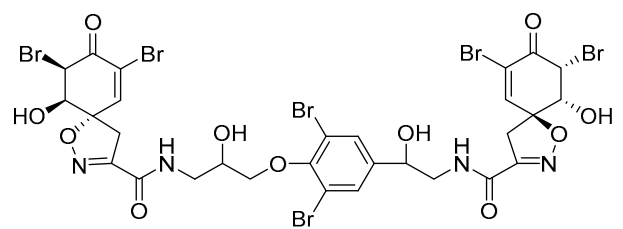

155

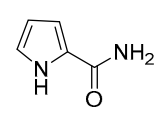

157

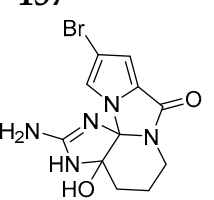

162<smiles>O=CNC(=O)c1ccc[nH]1</smiles>

158<smiles>CC1=CC(C)(C)N=C(C)C1=O</smiles>

159<smiles></smiles><smiles>[R]C(=O)c1cc(Br)c(Br)[nH]1</smiles>

164: $\mathrm{R}=\mathrm{OCH}_{3}$

163

165: $\mathrm{R}=\mathrm{NH}_{2}$

166: $\mathrm{R}=\mathrm{OH}$

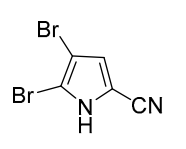

167<smiles>CC(C)CCCC(C)C1CCC2C3=C4CCC5C(C)C(O)CCC5(C)C4CCC3C21C</smiles>

183<smiles>Nc1nc(/C=C/CNC(=O)c2cc(Br)c(Br)[nH]2)c[nH]1</smiles>

168<smiles>NC/C=C/c1cnc(N)[nH]1</smiles>

184

Figure 20. Chemical structures of compounds 154-189. 


\subsection{Agelas sceptrum}

One novel $C_{29}$ sterol containing the typical nucleus of ergosterol, 26-nor-25-isopropyl-ergosta5,7,22E-trien-3 $\beta$-ol (190), was purified from the Jamaican A. sceptrum [78]. Sceptrin (191) was obtained from $A$. sceptrum collected at Glover Reef and found to have a broad spectrum of antimicrobial activities against $S$. aureus, B. subtilis, C. albicans, Pseudomonas aeruginosa, Alternaria sp. and Cladosporium cucumerinum [79]. Chemical study of the sponge from Bahamas afforded two hybrid pyrrole-imidazole alkaloids: 15'-oxoadenosceptrin (192) and decarboxyagelamadin C (193) (Figure 21) [80].<smiles>CC(C)CC(C)/C=C/[C@H](C)C1CCC2C3=CC=C4CC(O)CCC4(C)C3CCC21C</smiles>

190<smiles></smiles>

192<smiles></smiles>

191<smiles>NCCC(=O)c1cccc2c1NC(CNC(=O)c1cc(Br)c(Br)[nH]1)[C@H](c1cnc(N)[nH]1)O2</smiles>

193

Figure 21. Chemical structures of compounds 190-193.

\subsection{Agelas schmidtii}

Three monohydroxyl sterols (194-196) were isolated from the Caribbean Agelas schmidtii [81]. Additionally, four carotenoids named $\alpha$-carotene (197), isorenieratene (198), trikentriorhodin (199) and zeaxanthin (200) (Figure 22) were also derived from this sponge collected from West Indies [82].

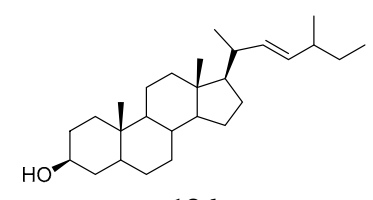

194<smiles>CC(C)=CCCC(C)C1CCC2C3=CCC4CC(O)CCC4(C)C3CCC21C</smiles>

196<smiles>CC1=CCCC(C)(C)C1/C=C/C(C)=C/C=C/C(C)=C/C=C/C=C(C)/C=C/C=C(C)/C=C/C1=C(C)CCCC1(C)C</smiles>

197<smiles>CC(/C=C/C=C(C)/C=C/c1c(C)ccc(C)c1C)=C\C=C\C=C(C)\C=C\C=C(C)\C=C\c1c(C)ccc(C)c1C</smiles>

198<smiles>CC(/C=C/C=C(C)/C=C/C=C(C)/C=C/C(C)=C/C=C/c1cccc(C)c1C)=C\C=C(O)\C(O)=C\C(=O)C1(C)CC(O)CC1(C)C</smiles>

199<smiles>CC1=C(/C=C/C(C)=C/C=C/C=C(C)/C=C/C=C(C)/C=C/C=C(C)/C=C/C2=C(C)C[C@@H](O)CC2(C)C)C(C)(C)CC(O)C1</smiles>

200

Figure 22. Chemical structures of compounds 194-200. 


\subsection{Agelas sventres}

Only one new bromopyrrole alkaloid, sventrin (201) (Figure 23), has been purified from the Caribbean sponge Agelas sventres. Biological assay showed that this chemical has feeding deterrent activity against omnivorous reef fish [83].<smiles>Cn1c(C(=O)NC/C=C/c2cnc(N)[nH]2)cc(Br)c1Br</smiles>

Figure 23. Chemical structure of compounds 201.

\subsection{Agelas wiedenmayeri}

Chemical investigation of Agelas wiedenmayeri from Florida Keys afforded one new pyrrole derivative, 4-bromopyrrole-2-carboxyhomoarginine (202) (Figure 24), which might be alternatively a biosynthetic precursor of hymenidin/oroidin-related alkaloids [84].

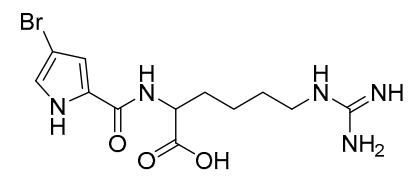

202

Figure 24. Chemical structure of compounds 202.

\subsection{Other Agelas spp.}

Eighty-nine secondary metabolites (203-291) were isolated and chemically identified from unclassified Agelas species and assorted into two classes, ionic and non-ionic compounds as below.

\subsubsection{Ionic Compounds}

As described above, ionic compounds are the major secondary metabolites of Agelas sponge, which can be grouped in bromine-containing and non-bromine-containing compounds. It is eminent that all ionic brominated metabolites were produced by the Okinawan Agelas spp. besides dibromoagelaspongin hydrochloride (203) [85]. Agelamadins A (204) and B (205), possessing an agelastatin-like tetracyclic moiety and an oroidin-like linear moiety, were shown to have antimicrobial activity against $B$. subtilis, $M$. luteus and C. neoformans [86]. The same specimen was also found to metabolize agelamadins C-F (206-209) and tauroacidin E (210) (Figure 25), of which 209 was the first occurrence bromopyrrole alkaloid for containing aminoimidazole and pyridinium moieties simultaneously $[87,88]$.

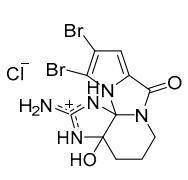

203

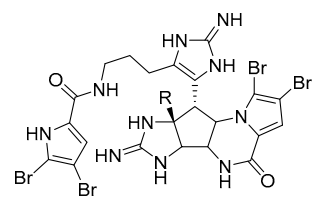

204: $\mathrm{R}=\mathrm{OCH}_{3}$

205: $\mathrm{R}=\mathrm{OH}$

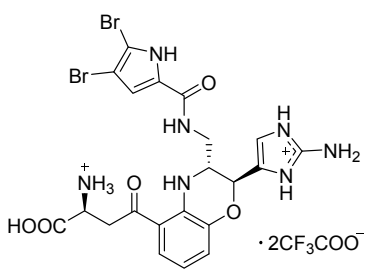

206

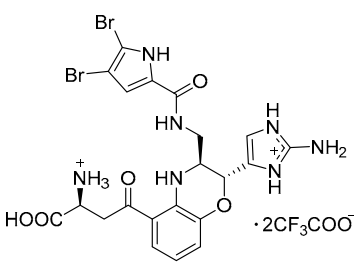

207

Figure 25. Cont. 


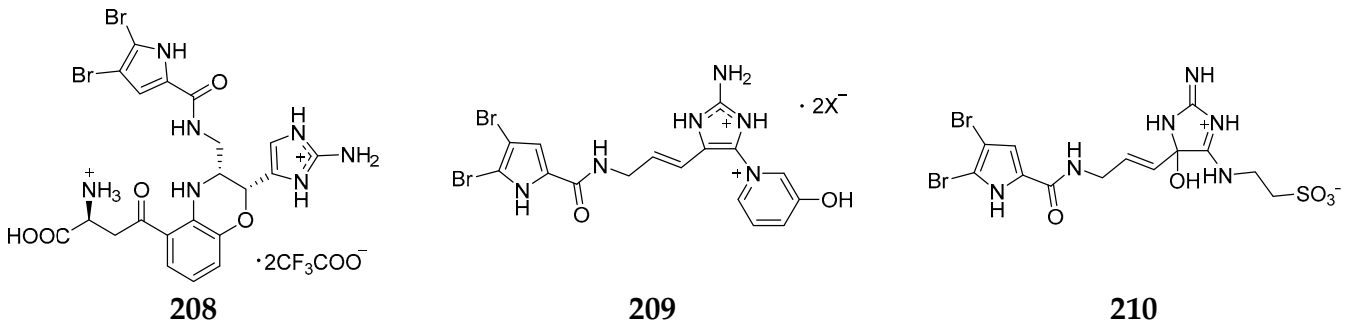

Figure 25. Chemical structures of compounds 203-210.

Twenty-one nagelamides (211-231) (Figure 26) have been characterized from the Okinawan Agelas spp. Nagelamides A-H (211-218) and O (219) were shown to possess antimicrobial activities against $M$. luteus, B. subtilis and E. coli. Compounds 211, 217 and 218 were shown to inhibit the growth of protein phosphatase type 2A with $\mathrm{IC}_{50}$ values of 48,13 and $46 \mu \mathrm{M}$, respectively [89,90]. Nagelamides $\mathrm{K}$ (220) and L (221) had inhibitory effect on M. luteus with a MIC value of $16.7 \mu \mathrm{g} / \mathrm{mL}$ [91]. Bioactivity test uncovered that nagelamides $\mathrm{M}(\mathbf{2 2 2})$ and $\mathrm{N}(\mathbf{2 2 3})$ exhibited inhibition against $A$. niger with the same MIC value of $33.3 \mu \mathrm{g} / \mathrm{mL}$ [92]. Nagelamides $\mathrm{Q}$ (224) and $\mathrm{R}$ (225), of which compound 225 possessed an oxazoline ring for the first time, showed antimicrobial activity against $B$. subtilis, Trichophyton mentagrophytes, C. neoformans, C. albicans and A. niger [93]. Nagelamides U (226) and V (227) were the first occurence for a bromopyrrole alkaloid containing a $\gamma$-lactam ring with an $N$-ethanesulfonic acid and guanidino moieties, while nagelamide $W$ (228) was the first monomeric bromopyrrole alkaloid with two aminoimidazole moieties in the molecule. Compounds 226 and 228 could inhibit against $C$. albicans with the same $\mathrm{IC}_{50}$ value of $4 \mu \mathrm{g} / \mathrm{mL}$ [94]. Nagelamides $\mathrm{X}$ (229) and $\mathrm{Y}(\mathbf{2 3 0})$ were unique for their novel tricyclic skeleton consisting of spiro-bonded tetrahydrobenzaminoimidazole and aminoimidazolidine moieties. In addition, nagelamide Z (231) was the first example for dimeric bromopyrrole alkaloid involving the C-8 position in dimerization and displayed strong antimicrobial activity against $C$. albicans with an $\mathrm{IC}_{50}$ value of $0.25 \mu \mathrm{g} / \mathrm{mL}$ [95].

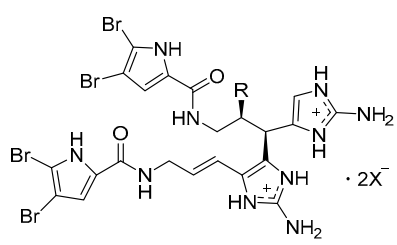

211: $\mathrm{R}=\mathrm{H}$

212: $\mathrm{R}=\mathrm{OH}$

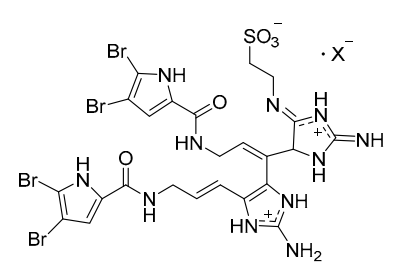

218

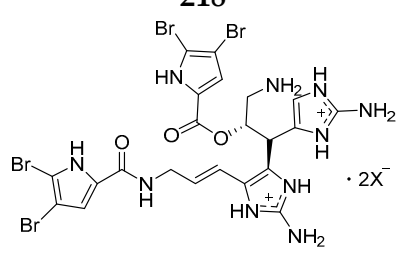

221

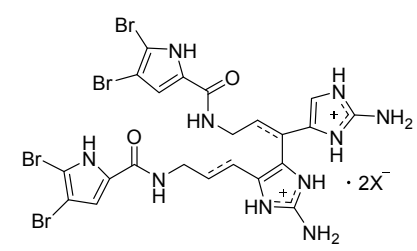

213: $\Delta^{9(10), 9^{\prime}\left(10^{\prime}\right)}$ 214: 9,9',10,10'-tetrahydro

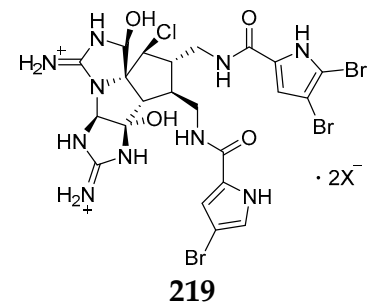<smiles>[NH3+]C1NC2N(CCS(=O)(=O)[O-])C(CNC(=O)c3cc(Br)c(Br)[nH]3)CC2(O)N1</smiles>

222

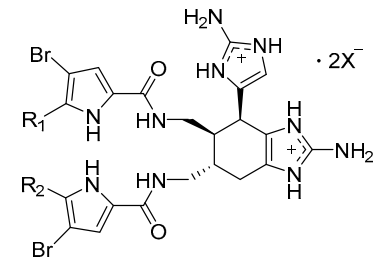

215: $\mathrm{R}_{1}=\mathrm{R}_{2}=\mathrm{H}$

216: $\mathrm{R}_{1}=\mathrm{Br}, \mathrm{R}_{2}=\mathrm{H}$

217: $R_{1}=R_{2}=B r$

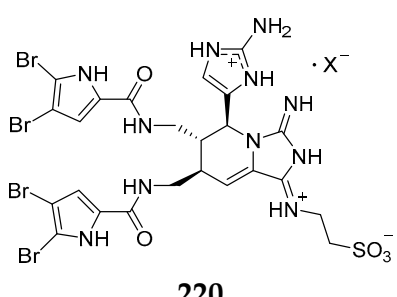

220

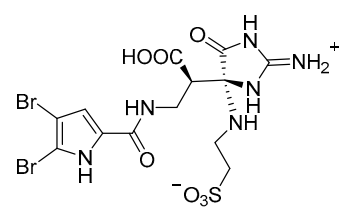

223

Figure 26. Cont. 
<smiles></smiles>

224

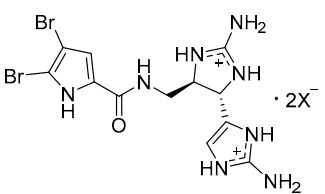

228

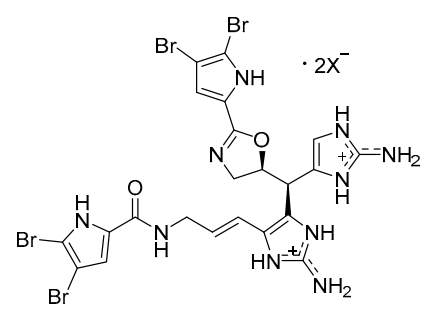

225

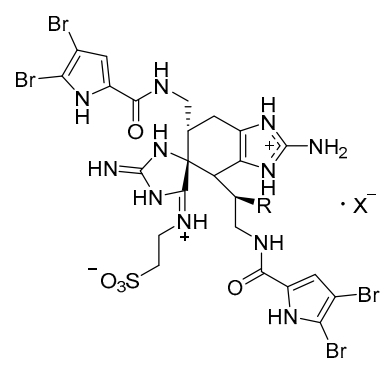

229: $\mathrm{R}=\mathrm{OH}$

230: $\mathrm{R}=\mathrm{H}$<smiles>N=C(N)NC1CC(CNC(=O)c2cc(Br)c(Br)[nH]2)N(CCS(=O)(=O)O)C1=O</smiles>

226: $\beta-\mathrm{H}$

227: $\alpha-\mathrm{H}$

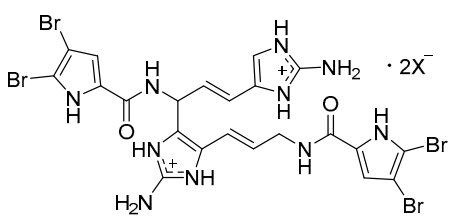

231

Figure 26. Chemical structures of compounds 211-231.

Eight new bromopyrrole alkaloids, 2-bromokeramadine (232), 2-bromo-9,10-dihydrokeramadine (233), tauroacidins C (234) and D (235), mukanadin G (236), 2-debromonagelamides U (237) and G (238), 2-debromonagelamide P (239), keramadine (240) and agelasine G (241) (Figure 27) were detected in the Okinawan Agelas spp. [96-99] Antimicrobial tests suggested that compound 236 exhibited inhibitory effects on C. albicans and C. neoformans with $\mathrm{IC}_{50}$ values of 16 and $8 \mu \mathrm{g} / \mathrm{mL}$, respectively [96]. Compounds 237 and 239 could inhibit the growth of $T$. mentagrophytes with $\mathrm{IC}_{50}$ values of 16 and $32 \mu \mathrm{g} / \mathrm{mL}$, respectively. Cytotoxicity assay revealed that 241 showed toxicity against murine lymphoma L1210 cells in vitro with an $\mathrm{IC}_{50}$ value of $3.1 \mu \mathrm{g} / \mathrm{mL}[97,99]$.<smiles></smiles>

232<smiles>NC1=NC(CC(=O)CNC(=O)c2cc(Br)c(Br)[nH]2)C(NCC[O+])N1</smiles>

235<smiles>[X]c1[nH]c2c(c1N)C1C(=O)NC(=O)C1C(CNC(=O)c1cc(Br)c[nH]1)C2</smiles>

238<smiles>[X]CCCNC(=O)c1cc(Br)c(Br)[nH]1</smiles>

233<smiles></smiles>

236<smiles>[X][C@H]1NC(=O)C(/C=C/CNC(=O)c2cc(Br)c[nH]2)(/C=C/CNC(=O)c2cc(Br)c[nH]2)N1</smiles>

239<smiles>COC(C=C1NC(=N)N=C1NCCC(=O)[O-])CNC(=O)c1cc(Br)c(Br)[nH]1</smiles>

234<smiles>N=C(N)NC1C[C@H](CNC(=O)c2cc(Br)c[nH]2)N(CCS(=O)(=O)[O-])C1=O</smiles>

237<smiles></smiles>

240

Figure 27. Cont. 


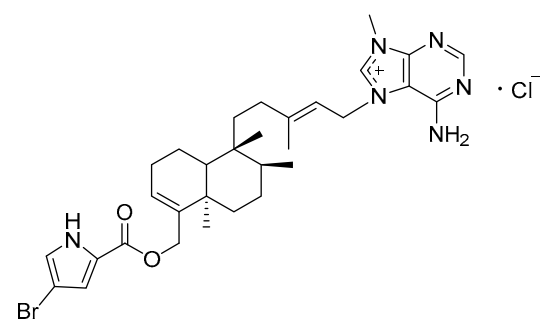

241

Figure 27. Chemical structures of compounds 232-241.

Nineteen non-bromine-containing ionic compounds have been isolated from unclassified Agelas spp., including eleven agalasines (242-252) from Okinawa [100,101], two agelasines (253 and 254) from Yap Island [102], four higher unsaturated 9- $\mathrm{N}$-methyladeninium bicyclic diterpenoids (255-258) from Papua New Guinea [103] and two quarternary 9-methyladenine salts of diterpenes agelines (259 and 260) from Argulpelu Reef [104]. Compounds 242-245 displayed strong inhibitory effects on $\mathrm{Na}, \mathrm{K}-\mathrm{ATP}$ ase and antimicrobial activities [100]. Agelasine M (255) exhibited potent activity against Trypanosoma brucei [103], while agelines A (259) and B (260) (Figure 28) showed mild ichthyotoxins and antimicrobial activities [104].

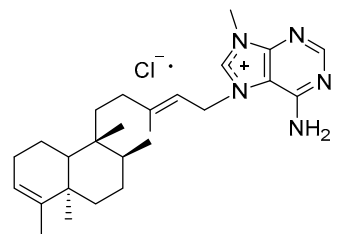

242<smiles></smiles>

245

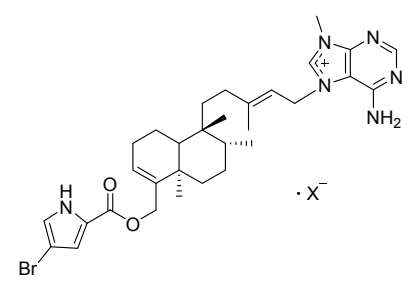

248

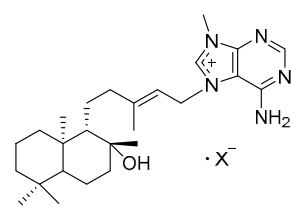

251<smiles></smiles>

243

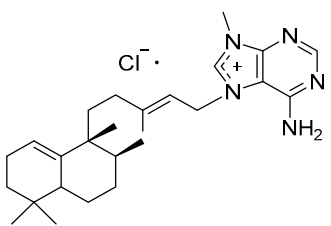

244

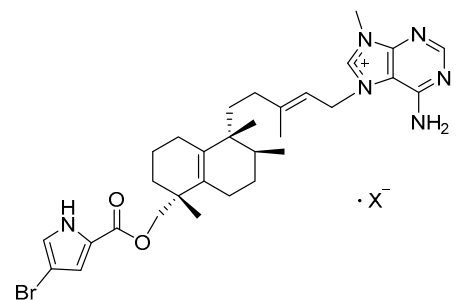

246

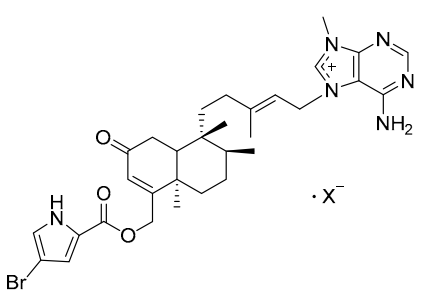

247

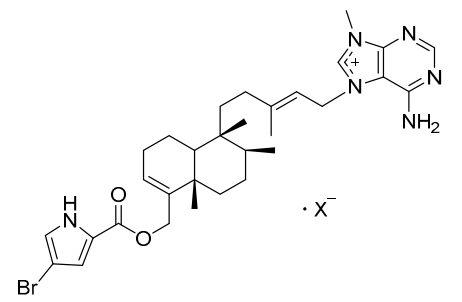

249

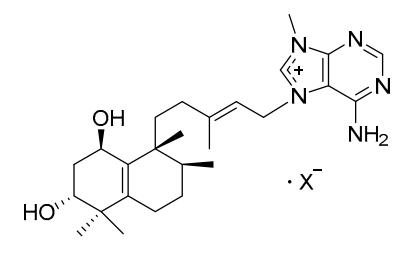

250

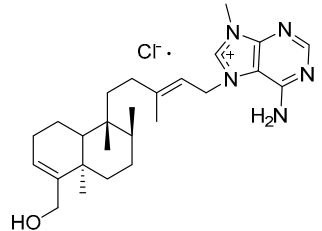

253

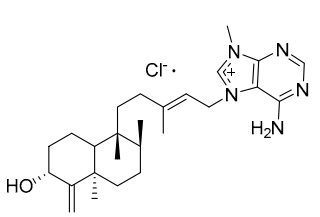

254

Figure 28. Cont. 


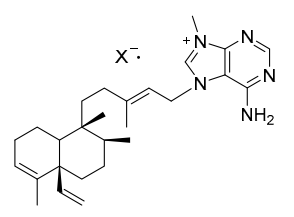

255

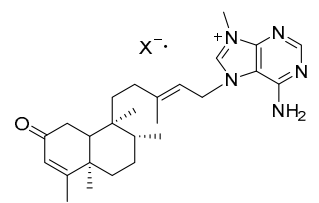

256

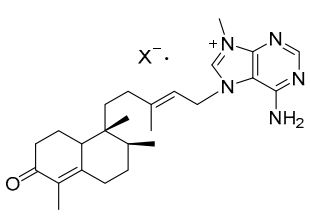

257

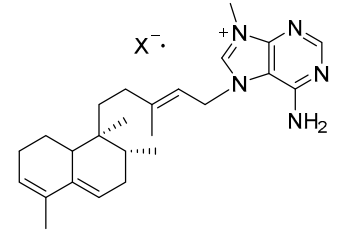

258

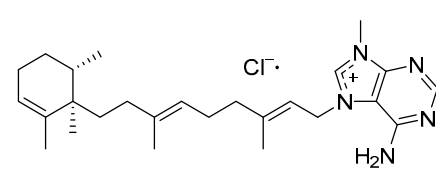

259

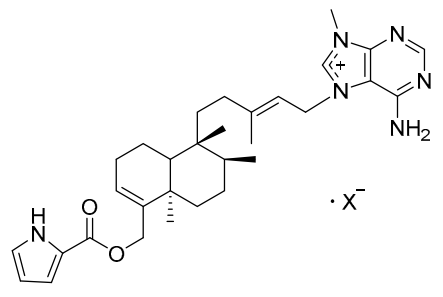

260

Figure 28. Chemical structures of compounds 242-260.

\subsubsection{Non-Ionic Compounds}

Since 1983, 29 non-ionic brominated metabolites (261-289) have been found in some unclassified Agelas spp. collected from the Okinawan Sea, the South China Sea, the Caribbean Sea, Papua New Guinea and the Indian Ocean. Agesamides A (261) and B (262) [105], benzosceptrin C (263) [106], nagelamide J (264) [107], nagelamide P (265), mukanadin E (266), mukanadin F (267) [92], nagelamide I (268) and 2,2'-didebromonagelamide B (269) [108] were obtained from the Okinawan specimen. Compound $\mathbf{2 6 4}$ had a cyclopentane ring fused to an amino imidazole ring and exhibited inhibitory effect on S. aureus and C. neoformans with MIC values of 8.35 and $16.7 \mu \mathrm{g} / \mathrm{mL}$, respectively. Compounds 268 and 269 were inactive against murine lymphoma L1210 and human epidermoid carcinoma KB cells in vitro. Chemical study of an unidentified Agelas spp. from the South China Sea afforded ten new non-ionic bromopyrrole derivatives, longamides D-F (270-272), 3-oxethyl-4-[1-(4,5-dibromopyrrole-2-yl)-formamido]-butanoic acid methyl ester (273), 2-oxethyl-3-[1-(4,5-dibromopyrrole-2-yl)-formamido]-methyl propionate (274), 9-oxethyl-mukanadin F (275) [109], hexazosceptrin (276), agelestes A (277) and B (278) and (9S, 10R, 9'S, 10'R)-nakamuric acid (279) [110]. Inspiringly, bioassay results revealed that (+)-270, (-)-271 and (+)-272 had significant antimicrobial activity against $C$. albicans with MIC values of 80,20 and $140 \mu \mathrm{M}$, respectively. Monobromoisophakellin (280) was isolated from the Caribbean Agelas sp. and shown to possess antifeedant activity against Thalassoma bifasciatum [111]. Chemical investigation of Agelas sponges from Wewak and Indonesian sea respectively led to the isolation of two phakellin alkaloids $(\mathbf{2 8 1}, \mathbf{2 8 2})$ and 5-bromophakelline (283) [112,113]. In addition, 2,3-dibromopyrrole (284) and 2,3-dibromo-5-methoxymethylpyrrole (285) belonging to non-ionic bromopyrrole alkaloid were purified from the marine sponge Agelas sp. [114]. Apart from alkaloids, four new brominated phospholipid fatty acids (286-289) (Figure 29) were also detected in the Caribbean Agelas spp. [115].

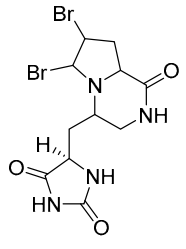

261

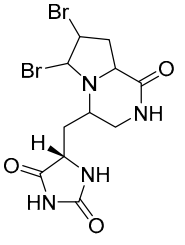

262

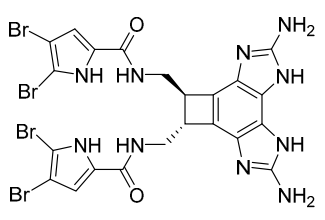

263

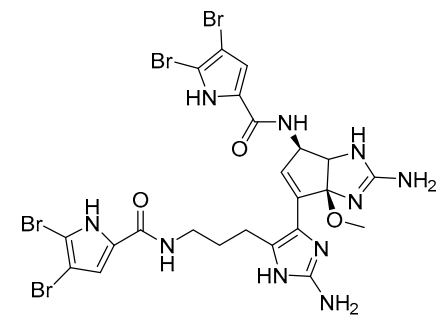

264

Figure 29. Cont. 
<smiles></smiles><smiles>Nc1cc(-c2nc(N)[nH]c2/C=C/CNC(=O)c2cc(Br)c[nH]2)nc(C/C=C/CNC(=O)c2cc(Br)c[nH]2)n1</smiles>
268<smiles>CCOC(=O)C1CNC(=O)c2cc(Br)c(Br)n21</smiles>

(+)-271<smiles>CCOC(CNC(=O)c1cc(Br)c(Br)[nH]1)C(=O)OC</smiles><smiles>CCOC(C=C1N[C@@H]2NC(=O)N[C@H]1NC2=O)CNC(=O)c1cc(Br)c(Br)[nH]1</smiles>

$( \pm)-274$<smiles>CCC(CNC(=O)c1cc(Br)c[nH]1)C(CNC(=O)c1cc(Br)c[nH]1)C(C(=O)O)c1cnc(N)[nH]1</smiles>

279<smiles>Brc1cc[nH]c1Br</smiles>

284<smiles>CN(CCCCCNC(=N)N)C(=O)c1cc(Br)c(Br)[nH]1</smiles><smiles></smiles>

269<smiles>O=C1NC(=O)/C(=C/C(O)CNC(=O)c2cc(Br)c(Br)[nH]2)N1</smiles>

267<smiles>CCNC(=O)C(OCC)C1CN(C(=O)C(=O)OCC)NC(=O)c2c(Br)cc(Br)n21</smiles>

(+)-270

$(-)-270$<smiles>CCCCOC(=O)C(Br)C1CNC(=O)c2cc(Br)c(Br)n21</smiles>

(+)-272

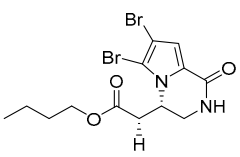

$(-)-272$

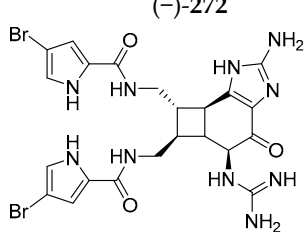

276<smiles>[R]c1c(Br)cc2n1C1C3N(CCN3C2N)C(=O)N1C</smiles>

281: $\mathrm{R}=\mathrm{Br}$

282: $\mathrm{R}=\mathrm{H}$<smiles>C=C/C=C\CCC/C(Br)=C/CCCC(=O)O</smiles>

286: $n=13$

287: $n=14$<smiles>CCOC(CNC(=O)c1cc(Br)c(Br)[nH]1)CC(=O)OC</smiles>

$( \pm)-273$

277: $\mathrm{R}=\mathrm{H}$

278: $\mathrm{R}=\mathrm{CH}_{3}$<smiles></smiles>

283<smiles>C/C=C/CC/C(Br)=C/CCCC(=O)O</smiles>

288: $n=12$

289: $n=13$

Figure 29. Chemical structures of compounds 261-289.

Only two non-ionic metabolites without bromine, agelasidine A (290) and agelagalastatin (291) (Figure 30), have been detected in two unclassified specimens of Agelas sp. Compound 290 was the first marine natural substance possessing sulfone and guanidine units purified from the Okinawan sample and showed antispasmodic activity [116]. It was notable that compound $\mathbf{2 4}$ from the Caribbean A. clathrodes is the optimal isomer of $\mathbf{2 9 0}$. Compound $\mathbf{2 9 1}$ was a new GSL derived from Agelas sp. collected in Papua New Guinea and found to exhibit significant in vitro activity against human cancer cell lines with lung NCI-H460 GI $500.77 \mu \mathrm{g} / \mathrm{mL}$ to ovary OVCAR-3 GI ${ }_{50} 2.8 \mu \mathrm{g} / \mathrm{mL}$ [117].

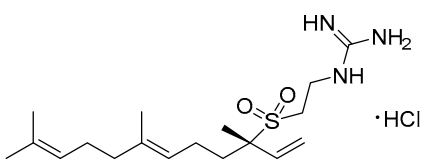

290

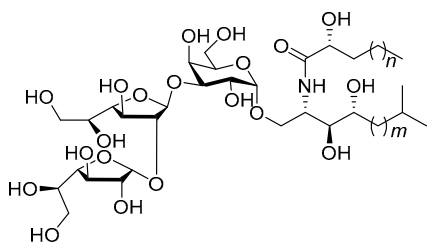

291: $n=21$ or $20, m=10$ or 11

Figure 30. Chemical structures of compounds 290 and 291. 
Table 1. Agelas-derived secondary metabolites.

\begin{tabular}{|c|c|c|c|}
\hline Organism & Locality & Secondary Metabolite & References \\
\hline Agelas axifera & the Republic of Palau & axistatins 1 (1), 2 (2), $3(3)$ & [4] \\
\hline A. cerebrum & Caribbean & 5-bromopyrrole-2-carboxylic acid (4), 4-bromopyrrole-2-carboxylic acid (5), 3,4-bromopyrrole-2-carboxylic acid (6) & [6] \\
\hline A. ceylonica & the Mandapam coast & hanishin (7) & [7] \\
\hline A. citrina & Caribbean & (-)-agelasidine E (8), (-)-agelasidine F (9), agelasine $\mathrm{N}(\mathbf{1 0})$, citrinamines A-D (11-14), $N$-methylagelongine (15) & {$[9,10]$} \\
\hline A. clathrodes & $\begin{array}{l}\text { Grand Bahamas Island } \\
\text { Caribbean } \\
\text { South China Sea }\end{array}$ & $\begin{array}{l}\text { clarhamnoside (16) } \\
\text { clathrosides A-C (17-19), isoclathrosides A-C (20-22), glycosphingolipid (23), (-)-agelasidine A (24), (-)-agelasidine C (25), } \\
\text { (-)-agelasidine D (26), lathramides A (27) and B (28), clathrodin (29), dispacamides A-D (31-34) } \\
\text { 3,3-bis(uracil---yl)-propan-1-aminium (30) }\end{array}$ & $\begin{array}{l}{[11]} \\
{[12-17,19,20]} \\
{[18]}\end{array}$ \\
\hline A. conifera & $\begin{array}{l}\text { Florida Keys } \\
\text { Belize } \\
\text { Caribbean } \\
\text { Puerto Rico }\end{array}$ & $\begin{array}{l}\text { bromosceptrin (35) } \\
\text { debromosceptrin (36) } \\
\text { bromopyrroles (37-43), glycosphingolipid (45) } \\
\text { coniferoside (44) }\end{array}$ & $\begin{array}{l}{[21]} \\
{[22]} \\
{[23,24,26]} \\
{[25]}\end{array}$ \\
\hline A. dendromorpha & $\begin{array}{c}\text { the Coral Sea } \\
\text { the New Caledonia }\end{array}$ & $\begin{array}{l}\text { agelastatin } \mathrm{A}(46) \\
\text { agelastatins } \mathrm{E}(47) \text { and } \mathrm{F}(48)\end{array}$ & $\begin{array}{l}{[27]} \\
{[28]}\end{array}$ \\
\hline A. dispar & $\begin{array}{c}\text { Caribbean } \\
\text { San Salvador Island }\end{array}$ & $\begin{array}{l}\text { dispyrin (49), dibromoagelaspongin methyl ether (50), longamide B (51), clathramides C (52) and D (53), } \\
\text { aminozooanemonin (55), pyridinebetaines A (56) and B (57) } \\
\text { triglycosylceramide (54) } \\
\text { agelasine (58) }\end{array}$ & $\begin{array}{c}{[29,30,32]} \\
{[31]} \\
{[33]}\end{array}$ \\
\hline A. gracilis & South Japan & gracilioethers A-C (59-61) & [34] \\
\hline A. linnaei & Indonesia & brominated pyrrole derivatives (62-72) & [35] \\
\hline A. longissima & Caribbean & agelongine (73), 3,7-dimethylisoguanine (74), longamide (75), glycosphingolipids (76 and 77) & [36-39] \\
\hline A. mauritiana & $\begin{array}{l}\text { South China Sea } \\
\text { Enewetak } \\
\text { Pohnpei } \\
\text { Solomon Islands } \\
\text { Fiji } \\
\text { Hachijo-jima Island } \\
\text { the Pacific sea } \\
\text { Okinawa } \\
\text { Kagoshima }\end{array}$ & $\begin{array}{l}\text { (-)-80-oxo-agelasine B (78), (+)-agelasine B (79), (+)-8'-oxo-agelasine C (80), agelasine V }(\mathbf{8 1}),(+)-8^{\prime} \text {-oxo-agelasine E (82), } \\
\text { 8'-oxo-agelasine D (83), ageloxime B (84), (+)-2-oxo-agelasidine C (85), 4-bromo- } N \text {-(butoxymethyl)-1H-pyrrole- } \\
\text { 2-carboxamide (95) } \\
\text { agelasimine A (86), agelasimine B (87), purino-diterpene (88), 5-debromomidpacamide (96) } \\
\text { epi-agelasine C (89) } \\
\text { agelasines J (90), K (91) and L (92), debromodispacamides B (93) and D (94) } \\
\text { mauritamide A (97) } \\
\text { mauritiamine (98) } \\
\text { ebromokeramadine (99), benzosceptrin A (100), nagelamides S (101) and T (102) } \\
\text { agelasphins (103-110) } \\
\text { isotedanin (111), isoclathriaxanthin (112) }\end{array}$ & $\begin{array}{c}{[40,41]} \\
{[42,43,47]} \\
{[44]} \\
{[45,46]} \\
{[48]} \\
{[49]} \\
{[50,51]} \\
{[52,53]} \\
{[54]}\end{array}$ \\
\hline
\end{tabular}


Table 1. Cont.

\begin{tabular}{|c|c|c|c|}
\hline Organism & Locality & Secondary Metabolite & References \\
\hline A. nakamurai & $\begin{array}{l}\text { Okinawa } \\
\text { Indonesia } \\
\text { South China Sea } \\
\text { Papua New Guinea } \\
\text { South China Sea } \\
\text { Japan } \\
\text { Indonesia } \\
\text { Indopacific }\end{array}$ & $\begin{array}{l}\text { agelasidines B (113) and C (114), nakamurols A-D (115-118), 2-oxoagelasiines A (119) and F (120), } \\
\text { 10-hydro-9-hydroxyagelasine F (121), agelasines E (122) and F (123), slagenins A-C (140-142), mukanadins A-C (143-145) } \\
\text { (-)-agelasine D (124), (-)-ageloxime D (125) } \\
\text { isoagelasine C (126), isoagelasidine B (127) } \\
\text { diterpene (128), bromopyrrole alkaloids (134 and 135) } \\
\text { nakamurines A-E (129-133) } \\
\text { ageladine A (136) } \\
\text { longamide C (137) } \\
\text { nakamuric acid (138) and its methyl ester (139) }\end{array}$ & $\begin{array}{l}{[55-58,65,66]} \\
{[35]} \\
{[59]} \\
{[60]} \\
{[59,61]} \\
{[63]} \\
{[35]} \\
{[64]}\end{array}$ \\
\hline A. nemoechinata & $\begin{array}{l}\text { South China Sea } \\
\text { Okinawa }\end{array}$ & $\begin{array}{l}\text { nemoechines A-D (146-149), nemoechioxide A (150), nemoechines F (151) and G (152) } \\
\text { oxysceptrin (153) }\end{array}$ & $\begin{array}{c}{[67,68]} \\
{[69]}\end{array}$ \\
\hline A. oroides & $\begin{array}{l}\text { the Great Barrier Reef } \\
\text { Mediterranea Sea } \\
\text { Naples } \\
\text { the Northern Aegean Sea }\end{array}$ & $\begin{array}{l}\text { agelorin A (154), agelorin B (155), 11-epi-fistularin-3 (156), pyrrole-2-carboxamide (157), N-formyl-pymole-2-carboxamid (158), } \\
\text { 2,4,6,6-tetramethyl-3(6H)-pyridone (159) } \\
\text { cyclooroidin (160) and taurodispacamide A (161), monobromoagelaspongin (162), (-)-equinobetaine B (163) } \\
\text { bromopyrroles (164-168), sterols (169-183) } \\
\text { 3-amino-1-(2-aminoimidazoyl)-prop-1-ene (184), taurine (185), fatty acid mixtures (186-189) }\end{array}$ & $\begin{array}{c}{[70-72]} \\
{[73,74]} \\
{[75,76]} \\
{[77]}\end{array}$ \\
\hline A. sceptrum & $\begin{array}{l}\text { Jamaica } \\
\text { Belize } \\
\text { Bahamas }\end{array}$ & $\begin{array}{l}\text { 26-nor-25-isopropyl-ergosta-5,7,22 E-trien-3ß-ol (190) } \\
\text { sceptrin (191) } \\
15^{\prime} \text {-oxoadenosceptrin (192), decarboxyagelamadin C (193) }\end{array}$ & $\begin{array}{l}{[78]} \\
{[79]} \\
{[80]}\end{array}$ \\
\hline A. schmidtii & $\begin{array}{l}\text { Caribbean } \\
\text { West Indies }\end{array}$ & $\begin{array}{l}\text { monohydroxyl sterols (194-196) } \\
\alpha \text {-carotene (197), isorenieratene (198), trikentriorhodin (199) and zeaxanthin (200) }\end{array}$ & $\begin{array}{l}{[81]} \\
{[82]}\end{array}$ \\
\hline A. sventres & Caribbean & sventrin (201) & [83] \\
\hline A. wiedenmayeri & Florida Keys & 4-bromopyrrole-2-carboxyhomoarginine (202) & [84] \\
\hline $\begin{array}{l}\text { Unclassified } \\
\text { Agelas sp. }\end{array}$ & $\begin{array}{c}\text { Yap Island } \\
\text { Papua New Guinea } \\
\text { Palau Island } \\
\text { South China Sea }\end{array}$ & $\begin{array}{l}\text { dibromoagelaspongin hydrochloride (203) } \\
\text { agelamadins A (204) and B (205), agelamadins C-F (206-209), tauroacidin E (210), nagelamides A-H (211-218), nagelamides } \\
\text { K-O (219-223), nagelamides Q (224) and R (225), nagelamides U-Z (226-231), 2-bromokeramadine (232), } \\
\text { 2-bromo-9,10-dihydrokeramadine (233), tauroacidins C (234) and D (235), mukanadin G (236), 2-debromonagelamides U (237) } \\
\text { and G (238), 2-debromonagelamide P (239), keramadine (240), agelasine G (241), agelasines A-D (242-245), agelasines } \\
\text { O-U (246-252), agesamides A (261) and B (262), benzosceptrin C (263), nagelamides J (264) and P (265), mukanadins E (266) } \\
\text { and F (267), nagelamide I (268), 2,2'-didebromonagelamide B (269), agelasidine A (290) } \\
\text { agelasines H (253) and I (254) } \\
\text { agelasine M (255), 2-oxo-agelasine B (256), gelasines A (257) and B (258), (-)-7-N-methyldibromophakellin (281), } \\
\text { (-)-7- } N \text {-methylmonobromophakellin (282), agelagalastatin (291) } \\
\text { agelines A (259) and B (260) } \\
\text { longamides D-F (270-272), 3-oxethyl-4-[1-(4,5-dibromopyrrole-2-yl)-formamido]-butanoic acid methyl ester (273), } \\
\text { 2-oxethyl-3-[1-(4,5-dibromopyrrole-2-yl)-formamido]-methyl propionate (274), 9-oxethyl-mukanadin F (275), } \\
\text { hexazosceptrin (276), agelestes A (277) and B (278) and (9S,10R,9'S,10'R)-nakamuric acid (279) } \\
\text { monobromoisophakellin (280), brominated phospholipid fatty acids (286-289) } \\
\text { 5-bromophakelline (283) } \\
\text { 2,3-dibromopyrrole (284) and 2,3-dibromo-5-methoxymethylpyrrole (285) }\end{array}$ & $\begin{array}{c}{[102]} \\
{[103,112,117]} \\
{[104]} \\
{[109,110]}\end{array}$ \\
\hline
\end{tabular}




\section{Conclusions}

Many efforts have been devoted to implement chemical investigation of Agelas sponges during the past 47 years, from 1971 to 2017. Meanwhile, great achievements have been made on chemical diversity of their secondary metabolites. Agelas sponges are widely distributed in the ocean, especially in the Okinawa Sea, the Caribbean Sea and the South China Sea. Deep ocean technologies for specimen collecting should be used to search more unknown species of Agelas sponges, such as manned and remotely operated underwater vehicles. Advanced separation methodologies should be deployed to explore more bioactive secondary metabolites of these sponges, such as UPLC-MS, metabolomics approach [74]. Furthermore, special attention should be paid to symbiotic microorganisms of Agelas sponges owing to the fact that a great number of therapeutic agents of marine sponges are biosynthesized by their symbiotic microbes [118]. By a combination of gene engineering, pathway reconstructing, enzyme engineering and metabolic networks, these microbes can be modified to produce more novel chemicals containing enhanced structural features or a large quantity of known valuable compounds for pharmaceutical production.

Acknowledgments: Financial support from the National Natural Science Foundation of China (Nos. 41776139 and 81773628), the Zhejiang Provincial Natural Science Foundation of China (LY16H300007 and LY16H300008) and the US National Cancer Institute grants (R01 CA 047135) are gratefully acknowledged.

Author Contributions: H.Z. conceived and wrote the paper; M.D. and J.C. searched and collected all references; and H.W., K.T. and P.C. made suggestive revision and provided eight photos of Agelas sponges.

Conflicts of Interest: The authors declare no conflict of interest.

\section{References}

1. Rane, R.; Sahu, N.; Shah, C.; Karpoormath, R. Marine bromopyrrole alkaloids: Synthesis and diverse medicinal applications. Curr. Top. Med. Chem. 2014, 14, 253-273. [CrossRef] [PubMed]

2. Ancheeva, E.; El-Neketi, M.; Song, W.; Lin, W.; Daletos, G.; Ebrahim, W.; Proksch, P. Structurally unprecedented metabolites from marine sponges. Curr. Org. Chem. 2017, 21, 426-449. [CrossRef]

3. Bickmeyer, U.; Drechsler, C.; Köck, M.; Assmann, M. Brominated pyrrole alkaloids from marine Agelas sponges reduce depolarization-induced cellular calcium elevation. Toxicon 2004, 44, 45-51. [CrossRef] [PubMed]

4. Pettit, G.R.; Tang, Y.; Zhang, Q.; Bourne, G.T.; Arm, C.A.; Leet, J.E.; Knight, J.C.; Pettit, R.K.; Chapuis, J.C.; Doubek, D.L.; et al. Isolation and structures of axistatins 1-3 from the Republic of Palau marine sponge Agelas axifera Hentschel. J. Nat. Prod. 2013, 76, 420-424. [CrossRef] [PubMed]

5. Assmann, M.; Soest, R.W.M.; Köck, M. Description of Agelas cerebrum, a new species and redescription of A. dilata. Proc. Biol. Soc. Wash. 2001, 114, 359-366.

6. Regalado, E.L.; Laguna, A.; Mendiola, J.; Thomas, O.P.; Nogueiras, C. Bromopyrrole alkaloids from the Caribbean sponge Agelas cerebrum. Quim. Nova 2011, 34, 289-291. [CrossRef]

7. Reddy, N.S.; Venkateswarlu, Y. S-(+)-methyl ester of hanishin from the marine sponge Agelas ceylonica. Biochem. Syst. Ecol. 2000, 28, 1035-1037. [CrossRef]

8. Umeyama, A.; Ito, S.; Yuasa, E.; Arihara, S.; Yamada, T. A new bromopyrrole alkaloid and the optical resolution of the racemate from the marine sponge Homaxinella sp. J. Nat. Prod. 1998, 61, 1433-1434. [CrossRef] [PubMed]

9. Stout, E.P.; Yu, L.C.; Molinski, T.F. Antifungal diterpene alkaloids from the Caribbean sponge Agelas citrina: Unified configurational assignments of agelasidines and agelasines. Eur. J. Org. Chem. 2012, 5131-5135. [CrossRef] [PubMed]

10. Cychon, C.; Lichte, E.; Köck, M. The marine sponge Agelas citrina as a source of the new pyrrole-imidazole alkaloids citrinamines A-D and N-methylagelongine. Beilstein J. Org. Chem. 2015, 11, 2029-2037. [CrossRef] [PubMed]

11. Costantino, V.; Fattorusso, E.; Imperatore, C.; Mangoni, A. Clarhamnoside, the first rhamnosylated $\alpha$-galactosylceramide from Agelas clathrodes. Improving spectral strategies for glycoconjugate structure determination. J. Org. Chem. 2004, 69, 1174-1179. [CrossRef] [PubMed] 
12. Costantino, V.; Fattorusso, E.; Imperatore, C.; Mangoni, A. Clathrosides and isoclathrosides, unique glycolipids from the Caribbean sponge Agelas clathrode. J. Nat. Prod. 2006, 69, 73-78. [CrossRef] [PubMed]

13. Costantino, V.; Fattorusso, E.; Mangoni, A. Glycosyl ceramide composition of the marine sponge Agelas clathrodes. Liebigs Ann. 1995, 1995, 1471-1475. [CrossRef]

14. Medeiros, A.M.; Lourenço, A.; Tavares, M.R.; Curto, M.J.M.; Feio, S.S.; Roseiro, J.C. (-)-Agelasidine A from Agelas clathrodes. Z. Naturforsch. 2006, 61, 472-476. [CrossRef]

15. Morales, J.J.; Rodríguez, A.D. (-)-Agelasidine C and (-)-agelasidine D, two new hypotaurocyamine diterpenoids from the Caribbean Sea sponge Agelas clathrodes. J. Nat. Prod. 1992, 55, 389-394. [CrossRef] [PubMed]

16. Cafieri, F.; Fattorusso, E.; Mangoni, A.; Taglialatela-Scafati, O. Clathramides, unique bromopyrrole alkaloids from the Caribbean sponge Agelas clathrodes. Tetrahedron 1996, 52, 13713-13720. [CrossRef]

17. Morales, J.J.; Rodríguez, A.D. The structure of clathrodin, a novel alkaloid isolated from the Caribbean Sea sponge Agelas clathrodes. J. Nat. Prod. 1991, 54, 629-631. [CrossRef]

18. Yang, F.; Ji, R.H.; Li, J.; Gan, J.H. N-containing metabolites from the marine sponge Agelas clathrodes. Nat. Prod. Commun. 2013, 8, 1713-1714. [PubMed]

19. Cafieri, F.; Carnuccio, R.; Fattorusso, E.; Taglialatela-Scafati, O.; Vallefuoco, T. Anti-histaminic activity of bromopyrrole alkaloids isolated from Caribbean Agelas sponges. Bioorg. Med. Chem. Lett. 1997, 7, 2283-2288. [CrossRef]

20. Cafieri, F.; Fattorusso, E.; Mangoni, A.; Taglialatela-Scafati, O. Dispacamides, anti-histamine alkaloids from Caribbean Agelas sponges. Tetrahedron Lett. 1996, 37, 3587-3590. [CrossRef]

21. Assmann, M.; Köck, M. Bromosceptrin, an alkaloid from the marine sponge Agelas conifera. Z. Naturforsch. C 2002, 57, 157-160. [CrossRef] [PubMed]

22. Shen, X.; Perry, T.L.; Dunbar, C.D.; Kelly-Borges, M.; Hamann, M.T. Debromosceptrin, an alkaloid from the Caribbean sponge Agelas conifera. J. Nat. Prod. 1998, 61, 1302-1303. [CrossRef] [PubMed]

23. Keifer, P.A.; Schwartz, R.E.; Koker, M.E.S.; Hughes, R.G.; Rittschof, D.; Rinehart, K. Bioactive bromopyrrole metabolites from the Caribbean sponge Agelas conifera. J. Org. Chem. 1991, 56, 2965-2975. [CrossRef]

24. Kobayashi, J.; Tsuda, M. Ageliferins, potent actomyosin ATPase activators from the Okinawan marine sponge Agelas sp. Tetrahedron 1990, 46, 5579-5586. [CrossRef]

25. La Clair, J.J.; Rodríguez, A.D. Isolation of the $\beta$-galactosphingolipid coniferoside using a tumor cell proteome reverse affinity protocol. Bioorg. Med. Chem. 2011, 19, 6645-6653. [CrossRef] [PubMed]

26. Costantino, V.; Fattorusso, E.; Mangoni, A. Glycosyl ceramides from the marine sponge Agelas conifera. Liebigs Ann. 1995, 2, 2133-2136. [CrossRef]

27. D'Ambrosio, M.; Guerriero, A.; Debitus, C.; Ribes, O.; Pusset, J.; Leroy, S.; Pietra, F. Agelastatin A, a new skeleton cytotoxic alkaloid of the oroidin family. Isolation from the Axinellid sponge Agelas dendromorpha of the Coral Sea. J. Chem. Soc. Chem. Commun. 1993, 16, 1305-1306. [CrossRef]

28. Tilvi, S.; Moriou, C.; Martin, M.T.; Gallard, J.F.; Sorres, J.; Patel, K.; Petek, S.; Debitus, C.; Ermolenko, L.; Al-Mourabit, A. Agelastatin E, agelastatin F, and benzosceptrin C from the marine sponge Agelas dendromorpha. J. Nat. Prod. 2010, 73, 720-723. [CrossRef] [PubMed]

29. Piňa, I.C.; White, K.N.; Cabrera, G.; Rivero, E.; Crews, P. Bromopyrrole carboxamide biosynthetic products from the Caribbean sponge Agelas dispar. J. Nat. Prod. 2007, 70, 613-617. [CrossRef] [PubMed]

30. Cafieri, F.; Fattorusso, E.; Taglialatela-scafati, O. Novel bromopyrrole alkaloids from the sponge Agelas dispar. J. Nat. Prod. 1998, 61, 122-125. [CrossRef] [PubMed]

31. Costantino, V.; Fattorusso, E.; Mangoni, A.; DiRosa, M.; Ianaro, A.; Maffia, P. Immunomodulating glycosyl ceramides from the marine sponge Agehs dispar. Tetrahedron 1996, 52, 1573-1578. [CrossRef]

32. Cafieri, F.; Fattorusso, E.; Taglialatela-scafati, O. Novel betaines from the marine sponge Agelas dispar. J. Nat. Prod. 1998, 61, 1171-1173. [CrossRef] [PubMed]

33. Cullen, E.; Devlin, J.P. Agelasine: A novel quaternary 9-methyladenine from the sponge Agelas dispar. Can. J. Chem. 1975, 53, 1690-1691. [CrossRef]

34. Ueoka, R.; Nakao, Y.; Kawatsu, S.; Yaegashi, J.; Matsumoto, Y.; Matsunaga, S.; Furihata, K.; Soest, R.W.M.; Fusetani, N. Gracilioethers A-C, antimalarial metabolites from the marine sponge Agelas gracilis. J. Org. Chem. 2009, 74, 4203-4207. [CrossRef] [PubMed] 
35. Hertiani, T.; Edrada-Ebel, R.; Ortlepp, S.; Soest, R.W.M.; Voogd, N.J.; Wray, V.; Hentschel, U.; Kozytska, S.; Müller, W.E.G.; Proksch, P. From anti-fouling to biofilm inhibition: New cytotoxic secondary metabolites from two Indonesian Agelas sponges. Bioorg. Med. Chem. 2010, 18, 1297-1311. [CrossRef] [PubMed]

36. Cafieri, F.; Fattorusso, E.; Mangoni, A.; Taglialatela-scafati, O. A novel bromopyrrole alkaloid from the sponge Agelas longissima with antiserotonergic activity. Bioorg. Med. Chem. Lett. 1995, 5, 799-804. [CrossRef]

37. Cafieri, F.; Fattorusso, E.; Mangoni, A.; Taglialatela-scafati, O. Longamide and 3,7-dimethylisoguanine, two novel alkaloids from the marine sponge Agelas longissima. Tetrahedron Lett. 1995, 36, 7893-7896. [CrossRef]

38. Cafieri, F.; Fattorusso, E.; Mahajnah, Y.; Mangoni, A. Longiside, a novel digalactosylceramide from the Caribbean sponge Agelas longissima. Liebigs Ann. Chem. 1994, 2, 1187-1189. [CrossRef]

39. Cafieri, F.; Fattorusso, E.; Mangoni, A.; Taglialatela-scafati, O. Glycosyl ceramide composition of the marine sponge Agelas longissima. Liebigs Ann. 1995, 1995, 1477-1481. [CrossRef]

40. Hong, L.L.; Sun, J.B.; Yang, F.; Liu, M.; Tang, J.; Sun, F.; Jiao, W.H.; Wang, S.P.; Zhang, W.; Lin, H.W. New diterpene alkaloids from the marine sponge Agelas mauritiana. RSC Adv. 2017, 7, 23970-23976. [CrossRef]

41. Yang, F.; Hamann, M.T.; Zou, Y.; Zhang, M.Y.; Gong, X.B.; Xiao, J.R.; Chen, W.S.; Lin, H.W. Antimicrobial metabolites from the Paracel Islands sponge Agelas mauritiana. J. Nat. Prod. 2012, 75, 774-778. [CrossRef] [PubMed]

42. Fathi-Afshar, R.; Allen, T.M.; Krueger, C.A.; Cook, D.K.; Clanachan, A.S.; Vriend, R.; Baer, H.P. Some pharmacological activities of novel adenine-related compounds isolated from a marine sponge Agelas mauritiana. Can. J. Physiol. Pharmacol. 1989, 67, 276-281. [CrossRef] [PubMed]

43. Nakatsu, T.; Faulkner, D.J.; Matsumoto, G.K.; Clardy, J. Structure of the diterpene portion of a novel base from the sponge Agelas mauritiana. Tetrahedron Lett. 1984, 25, 935-938. [CrossRef]

44. Hattori, T.; Adachi, K.; Shizuri, Y. New agelasine compound from the marine sponge Agelas mauritiana as an antifouling substance against macroalgae. J. Nat. Prod. 1997, 60, 411-413. [CrossRef]

45. Appenzeller, J.; Mihci, G.; Martin, M.T.; Gallard, J.F.; Menou, J.L.; Boury-Esnault, N.; Hooper, J.; Petek, S.; Chevalley, S.; Valentin, A.; et al. Agelasines J, K, and L from the Solomon Islands marine sponge Agelas cf. mauritiana. J. Nat. Prod. 2008, 71, 1451-1454. [CrossRef] [PubMed]

46. Vergne, C.; Appenzeller, J.; Ratinaud, C.; Martin, M.T.; Debitus, C.; Zaparucha, A.; Al-Mourabit, A. Debromodispacamides B and D: Isolation from the marine sponge Agelas mauritiana and stereoselective synthesis using a biomimetic proline route. Org. Lett. 2008, 10, 493-496. [CrossRef] [PubMed]

47. Fathi-Afshar, R.; Allen, T.M. Biologically active metabolites from Agelas mauritiana. Can. J. Chem. 1988, 66, 45-50. [CrossRef]

48. Jiménez, C.; Crews, P. Mauritamide A and accompanying oroidin alkaloids from the sponge Agelas mauritiana. Tetrahedron Lett. 1994, 35, 1375-1378. [CrossRef]

49. Tsukamoto, S.; Kato, H.; Hirota, H.; Fusetani, N. Mauritiamine, a new antifouling oroidin dimer from the marine sponge Agelas mauritiana. J. Nat. Prod. 1996, 59, 501-503. [CrossRef]

50. Schroif-Grégoire, C.; Appenzeller, J.; Debitus, C.; Zaparucha, A.; Al-Mourabit, A. Debromokeramadine from the marine sponge Agelas cf. mauritiana: Isolation and short regioselective and flexible synthesis. Tetrahedron 2015, 71, 3609-3613.

51. Appenzeller, J.; Tilvi, S.; Martin, M.T.; Gallard, J.F.; El-bitar, H.; Dau, E.T.H.; Debitus, C.; Laurent, D.; Moriou, C.; Al-Mourabit, A. Benzosceptrins A and B with a unique benzocyclobutane skeleton and nagelamide $\mathrm{S}$ and $\mathrm{T}$ from Pacific sponges. Org. Lett. 2009, 11, 4874-4877. [CrossRef] [PubMed]

52. Natori, T.; Koezuka, Y.; Higa, T. Agelasphins, novel $\alpha$-galactosylceramides from the marine sponge Agelas mauritianus. Tetrahedron Lett. 1993, 34, 5591-5592. [CrossRef]

53. Natori, T.; Morita, M.; Akimoto, K.; Koezuka, Y. Agelasphins, novel antitumor and immunostimulatory cerebrosides from the marine sponge Agelas mauritianus. Tetrahedron 1994, 50, 2771-2784. [CrossRef]

54. Tanaka, Y.; Katayama, T. The structures of isotedanin and isoclathriaxanthin in sea sponge Agelas mauritiana. Bull. Jpn. Soc. Sci. Fish. 1982, 48, 531-533. [CrossRef]

55. Nakamura, H.; Wu, H.; Kobayashi, J.; Kobayashi, M.; Ohizumi, Y.; Hirata, Y. Agelasidines. Novel hypotaurocyamine derivatives from the Okinawan Sea sponge Agelas nakamurai Hoshino. J. Org. Chem. 1985, 50, 2494-2497. [CrossRef]

56. Shoji, N.; Umeyama, A.; Teranaka, M.; Arihara, S. Four novel diterpenoids, including nakamurol A with a unique thelepogane skeleton, from the marine sponge Agelas nakamurai. J. Nat. Prod. 1996, 59, 448-450. [CrossRef] 
57. Abdjul, D.B.; Yamazaki, H.; Kanno, S.; Takahashi, O.; Kirikoshi, R.; Ukai, K.; Namikoshi, M. Structures and Biological evaluations of agelasines isolated from the Okinawan marine sponge Agelas nakamurai. J. Nat. Prod. 2015, 78, 1428-1433. [CrossRef] [PubMed]

58. Wu, H.; Nakamura, H.; Kobayashi, J.; Ohizumi, Y. Agelasine-E and -F, novel monocyclic diterpenoids with 9-methyladeninium unit possessing inhibitory effects on $\mathrm{Na}$, K-ATPase isolated from the Okinawan Sea sponge Agelas nakamurai Hoshino. Tetrahedron Lett. 1984, 25, 3719-3722. [CrossRef]

59. Chu, M.J.; Tang, X.L.; Qin, G.F.; Sun, Y.T.; Li, L.; Voogd, N.J.; Li, P.L.; Li, G.Q. Pyrrole derivatives and diterpene alkaloids from the South China Sea sponge Agelas nakamurai. Chem. Biodivers. 2017, 14, e1600446. [CrossRef] [PubMed]

60. Iwagawa, T.; Kaneko, M.; Okamura, H.; Nakatani, M.; Soest, R.W.M. New alkaloids from the Papua New Guinean sponge Agelas nakamurai. J. Nat. Prod. 1998, 61, 1310-1312. [CrossRef] [PubMed]

61. Chu, M.J.; Tang, X.L.; Qin, G.F.; Voogd, N.J.; Li, P.L.; Li, G.Q. Three new non-brominated pyrrole alkaloids from the South China Sea sponge Agelas nakamurai. Chin. Chem. Lett. 2017, 28, 1210-1213. [CrossRef]

62. Tanaka, N.; Kusama, T.; Kashiwada, Y.; Kobayashi, J. Bromopyrrole alkaloids from Okinawan marine sponges Agelas spp. Chem. Pharm. Bull. 2016, 64, 691-694. [CrossRef] [PubMed]

63. Fujita, M.; Nakao, Y.; Matsunaga, S.; Seiki, M.; Itoh, Y.; Yamashita, J.; Soest, R.W.M.; Fusetani, N. Ageladine A: An antiangiogenic matrixmetalloproteinase inhibitor from the marine sponge Agelas nakamurai. J. Am. Chem. Soc. 2003, 125, 15700-15701. [CrossRef] [PubMed]

64. Eder, C.; Proksch, P.; Wray, V.; Soest, R.W.M.; Ferdinandus, E.; Pattisina, L.A.; Sudarsono. New bromopyrrole alkaloids from the Indopacific sponge Agelas nakamurai. J. Nat. Prod. 1999, 62, 1295-1297. [CrossRef] [PubMed]

65. Tsuda, M.; Uemoto, H.; Kobayashi, J. Slagenins A-C, novel bromopyrrole alkaloids from marine sponge Agelas nakamurai. Tetrahedron Lett. 1999, 40, 5709-5712. [CrossRef]

66. Uemoto, H.; Tsuda, M.; Kobayashi, J. Mukanadins A-C, new bromopyrrole alkaloids from marine sponge Agelas nakamurai. J. Nat. Prod. 1999, 62, 1581-1583. [CrossRef] [PubMed]

67. An, L.; Song, W.; Tang, X.; Voogd, N.J.; Wang, Q.; Chu, M.; Li, P.; Li, G. Alkaloids and polyketides from the South China Sea sponge Agelas aff. nemoechinata. RSC Adv. 2017, 7, 14323-14329. [CrossRef]

68. Li, T.; Wang, B.; Voogd, N.J.; Tang, X.L.; Wang, Q.; Chu, M.J.; Li, P.L.; Li, G.Q. Two new diterpene alkaloids from the South China Sea sponge Agelas aff. nemoechinata. Chin. Chem. Lett. 2016, 27, 1048-1051. [CrossRef]

69. Kobayashi, J.; Tsuda, M.; Ohizumi, Y. A potent actomyosin ATPase activator from the Okinawan marine sponge Agelas cf. nemoechinata. Experientia 1991, 47, 301-304. [CrossRef] [PubMed]

70. König, G.M.; Wright, A.D. Agelorins A and B and 11-Epi-fistularin-3, three new antibacterial fistularin-3 derivatives from the tropical marine sponge Agelas oroides. Heterocycles 1993, 36, 1351-1358.

71. König, G.M.; Wright, A.D. Two new naturally occurring pyrrole derivatives from the tropical marine sponge Agelas oroides. Nat. Prod. Lett. 1994, 5, 141-146. [CrossRef]

72. König, G.M.; Wright, A.D. An unprecedented compound from the dichloromethane solubles of the tropical marine sponge Agelas oroides. Planta Med. 1998, 64, 88-89. [CrossRef] [PubMed]

73. Fattorusso, E.; Taglialatela-Scafati, O. Two novel pyrrole-imidazole alkaloids from the Mediterranean sponge Agelas oroides. Tetrahedron Lett. 2000, 41, 9917-9922. [CrossRef]

74. Sauleau, P.; Moriou, C.; Al Mourabit, A. Metabolomics approach to chemical diversity of the Mediterranean marine sponge Agelas oroides. Nat. Prod. Res. 2017, 31, 1625-1632. [CrossRef] [PubMed]

75. Forenza, S.; Minale, L.; Riccio, R. New bromo-pyrrole derivatives from the sponge Agelas oroides. Chem. Commun. 1971, 18, 1129-1130. [CrossRef]

76. Giacomo, G.D.; Dini, A.; Falco, B.; Marino, A.; Sica, D. Sterols from the sponge Agelas oroides. Comp. Biochem. Physiol. 1983, 74B, 499-501.

77. Tasdemir, D.; Topaloglu, B.; Perozzo, R.; Brun, R.; O’Neill, R.; Carballeira, N.M.; Zhang, X.; Tonge, P.J.; Linden, A.; Rüedi, P. Marine natural products from the Turkish sponge Agelas oroides that inhibit the enoyl reductases from Plasmodium falciparum, Mycobacterium tuberculosis and Escherichia coli. Bioorg. Med. Chem. 2007, 15, 6834-6845. [CrossRef] [PubMed]

78. Hu, J.F.; Kelly, M.; Hamann, M.T. 26-Nor-25-isopropyl-ergosta-5,7,22E-trien-3ß-ol: A new $\mathrm{C}_{29}$ sterol from the sponge Agelas sceptrum from Jamaica. Steroids 2002, 67, 743-747. [CrossRef]

79. Walker, R.P.; Faulkner, D.J. Sceptrin, an antimicrobial agent from the sponge Agelas sceptrum. J. Am. Chem. Soc. 1981, 103, 6772-6773. [CrossRef] 
80. Muûoz, J.; Köck, M. Hybrid pyrrole-imidazole alkaloids from the sponge Agelas sceptrum. J. Nat. Prod. 2016, 79, 434-437.

81. Duque, C.; Castillo, G.; Buitrago, S.; Zea, O.O.S. Three monohydroxyl sterols from Agelas schmidti (Wilson, 1902). Rev. Colomb. Quim. 1994, 23, 63-72.

82. Buchecker, R.; Eugster, C.H.; Litchfield, C. Carotenoids from marine sponges (Porifera): Isolation and structure of the seven main carotenoids from Agelas schmidtii. Helv. Chim. Acta 1977, 60, 2780-2788. [CrossRef]

83. Assmann, M.; Zea, S.; Köck, M. Sventrin, a new bromopyrrole alkaloid from the Caribbean sponge Agelas sventres. J. Nat. Prod. 2001, 64, 1593-1595. [CrossRef] [PubMed]

84. Assmann, M.; Lichte, E.; Soest, R.W.M.; Köck, M. New bromopyrrole alkaloid from the marine sponge Agelas wiedenmayeri. Org. Lett. 1999, 1, 455-457. [CrossRef]

85. Fedoreev, S.A.; Ilyin, S.G.; Utkina, N.K.; Maxtmov, O.B.; Reshetnyak, M.V. The structure of dibromoagelaspongin-A novel bromine-containing guanidine derivative from the marine sponge Agelas sp. Tetrahedron 1989, 45, 3487-3492. [CrossRef]

86. Kusama, T.; Tanaka, N.; Sakai, K.; Gonoi, T.; Fromont, J.; Kashiwada, Y.; Kobayashi, J. Agelamadins A and B, dimeric bromopyrrole alkaloids from a marine sponge Agelas sp. Org. Lett. 2014, 16, 3916-3918. [CrossRef] [PubMed]

87. Kusama, T.; Tanaka, N.; Sakai, K.; Gonoi, T.; Fromont, J.; Kashiwada, Y.; Kobayashi, J. Agelamadins C-E, bromopyrrole alkaloids comprising oroidin and 3-hydroxykynurenine from a marine sponge Agelas sp. Org. Lett. 2014, 16, 5176-5179. [CrossRef] [PubMed]

88. Kusama, T.; Tanaka, N.; Kashiwada, Y.; Kobayashi, J. Agelamadin F and tauroacidin E, bromopyrrole alkaloids from an Okinawan marine sponge Agelas sp. Tetrahedron Lett. 2015, 56, 4502-4504. [CrossRef]

89. Endo, T.; Tsuda, M.; Okada, T.; Mitsuhashi, S.; Shima, H.; Kikuchi, K.; Mikami, Y.; Fromont, J.; Kobayashi, J. Nagelamides A-H, new dimeric bromopyrrole alkaloids from marine sponge Agelas Species. J. Nat. Prod. 2004, 67, 1262-1267. [CrossRef] [PubMed]

90. Yasuda, T.; Araki, A.; Kubota, T.; Ito, J.; Mikami, Y.; Fromont, J.; Kobayashi, J. Bromopyrrole alkaloids from marine sponges of the genus Agelas. J. Nat. Prod. 2009, 72, 488-491. [CrossRef] [PubMed]

91. Araki, A.; Kubota, T.; Tsuda, M.; Mikami, Y.; Fromont, J.; Kobayashi, J. Nagelamides K and L, dimeric bromopyrrole alkaloids from sponge Agelas Species. Org. Lett. 2008, 10, 2099-2102. [CrossRef] [PubMed]

92. Kubota, T.; Araki, A.; Ito, J.; Mikami, Y.; Fromont, J.; Kobayashi, J. Nagelamides M and N, new bromopyrrole alkaloids from sponge Agelas species. Tetrahedron 2008, 64, 10810-10813. [CrossRef]

93. Araki, A.; Kubota, T.; Aoyama, K.; Mikami, Y.; Fromont, J.; Kobayashi, J. Nagelamides Q and R, novel dimeric bromopyrrole alkaloids from sponges Agelas sp. Org. Lett. 2009, 11, 1785-1788. [CrossRef] [PubMed]

94. Tanaka, N.; Kusama, T.; Takahashi-Nakaguchi, A.; Gonoi, T.; Fromont, J.; Kobayashi, J. Nagelamides U-W, bromopyrrole alkaloids from a marine sponge Agelas sp. Tetrahedron Lett. 2013, 54, 3794-3796. [CrossRef]

95. Tanaka, N.; Kusama, T.; Takahashi-Nakaguchi, A.; Gonoi, T.; Fromont, J.; Kobayashi, J. Nagelamides X-Z, dimeric bromopyrrole alkaloids from a marine sponge Agelas sp. Org. Lett. 2013, 15, 3262-3265. [CrossRef] [PubMed]

96. Kusama, T.; Tanaka, N.; Takahashi-Nakaguchi, A.; Gonoi, T.; Fromont, J.; Kobayashi, J. Bromopyrrole alkaloids from a marine sponge Agelas sp. Chem. Pharm. Bull. 2014, 62, 499-503. [CrossRef] [PubMed]

97. Nakamura, K.; Kusama, T.; Tanaka, N.; Sakai, K.; Gonoi, T.; Fromont, J.; Kobayashi, J. 2-Debromonagelamide U, 2-debromomukanadin G, and 2-debromonagelamide P from marine sponge Agelas sp. Heterocycles 2015, 90, 425-431.

98. Nakamura, H.; Ohizumi, Y.; Kobayashi, J. Keramadine, a novel antagonist of serotonergic receptors isolated from the Okinawan Sea sponge Agelas sp. Tetrahedron Lett. 1984, 25, 2475-2478. [CrossRef]

99. Ishida, K.; Ishibashi, M.; Shigemori, H.; Sasaki, T.; Kobayashi, J. Agelasine G, a new antileukemic alkaloid from the Okinawan marine sponge Agelas sp. Chem. Pharm. Bull. 1992, 40, 766-767. [CrossRef] [PubMed]

100. Nakamura, H.; Wu, H.; Ohizumi, Y.; Hirata, Y. Agelasine-A, -B, -C and -D, novel bicyclic diterpenoids with a 9-methyladeninium unit possessing inhibitory effects on $\mathrm{Na}, \mathrm{K}$-ATPase from the Okinawa Sea sponge Agelas sp. Tetrahedron Lett. 1984, 25, 2989-2992. [CrossRef]

101. Kubota, T.; Iwai, T.; Takahashi-Nakaguchi, A.; Fromont, J.; Gonoi, T.; Kobayashi, J. Agelasines O-U, new diterpene alkaloids with a 9- $\mathrm{N}$-methyladenine unit from a marine sponge Agelas sp. Tetrahedron 2012, 68, 9738-9744. [CrossRef] 
102. Fu, X.; Schmiz, F.J.; Tanner, R.S.; Kelly-Borges, M. Agelasines H and I, 9-methyladenine-containing diterpenoids from an Agelas sponge. J. Nat. Prod. 1998, 61, 548-550. [CrossRef] [PubMed]

103. Calcul, L.; Tenney, K.; Ratnam, J.; Mckerrow, J.H.; Crews, P. Structural variations to the 9-N-methyladeninium diterpenoid hybrid commonly isolated from Agelas sponges. Aust. J. Chem. 2010, 63, 915-921. [CrossRef]

104. Capon, R.J.; Faulkner, D.J. Antimicrobial metabolites from a Pacific sponge, Agelas sp. J. Am. Chem. Soc. 1984, 106, 1819-1822. [CrossRef]

105. Tsuda, M.; Yasuda, T.; Fukushi, E.; Kawabata, J.; Sekiguchi, M.; Fromont, J.; Kobayashi, J. Agesamides A and B, bromopyrrole alkaloids from sponge Agelas Species: Application of DOSY for chemical screening of new metabolites. Org. Lett. 2006, 8, 4235-4238. [CrossRef] [PubMed]

106. Kubota, T.; Araki, A.; Yasuda, T.; Tsuda, M.; Fromont, J.; Aoyama, K.; Mikami, Y.; Wälchli, M.R.; Kobayashi, J. Benzosceptrin C, a new dimeric bromopyrrole alkaloid from sponge Agelas sp. Tetrahedron Lett. 2009, 50, 7268-7270. [CrossRef]

107. Araki, A.; Tsuda, M.; Kubota, T.; Mikami, Y.; Fromont, J.; Kobayashi, J. Nagelamide J, a novel dimeric bromopyrrole alkaloid from a sponge Agelas species. Org. Lett. 2007, 9, 2369-2371. [CrossRef] [PubMed]

108. Iwai, T.; Kubota, T.; Fromont, J.; Kobayashi, J. Nagelamide I and 2,2'-didebromonagelamide B, new dimeric bromopyrrole-imidazole alkaloids from a marine sponge Agelas sp. Chem. Pharm. Bull. 2014, 62, 213-216. [CrossRef] [PubMed]

109. Zhu, Y.; Wang, Y.; Gu, B.B.; Yang, F.; Jiao, W.H.; Hu, G.H.; Yu, H.B.; Han, B.N.; Zhang, W.; Shen, Y.; Lin, H.W. Antifungal bromopyrrole alkaloids from the South China Sea sponge Agelas sp. Tetrahedron 2016, 72, 2964-2971. [CrossRef]

110. Sun, Y.T.; Lin, B.; Li, S.G.; Liu, M.; Zhou, Y.J.; Xu, Y.; Hua, H.M.; Lin, H.W. New bromopyrrole alkaloids from the marine sponge Agelas sp. Tetrahedron 2017, 73, 2786-2792. [CrossRef]

111. Assmann, M.; Köck, M. Monobromoisophakellin, a new bromopyrrole alkaloid from the Caribbean sponge Agelas sp. Z. Naturforsch. 2002, 57, 153-156. [CrossRef]

112. Gautschi, J.T.; Whitman, S.; Holman, T.R.; Crews, P. An analysis of phakellin and oroidin structures stimulated by further study of an Agelas sponge. J. Nat. Prod. 2004, 67, 1256-1261. [CrossRef] [PubMed]

113. Abdjul, D.B.; Yamazaki, H.; Kanno, S.I.; Tomizawa, A.; Rotinsulu, H.; Wewengkang, D.S.; Sumilat, D.A.; Ukai, K.; Kapojos, M.M.; Namikoshi, M. An anti-mycobacterial bisfunctionalized sphingolipid and new bromopyrrole alkaloid from the Indonesian marine sponge Agelas sp. J. Nat. Med. 2017, 71, 531-536. [CrossRef] [PubMed]

114. Tada, H.; Tozyo, T. Two bromopyrroles from a marine sponge Agelas sp. Chem. Lett. 1988, 117, $803-804$. [CrossRef]

115. Carballeira, N.M.; Emiliano, A. Novel brominated phospholipid fatty acids from the Caribbean sponge Agelas sp. Lipids 1993, 28, 763-766. [CrossRef] [PubMed]

116. Nakamura, H.; Wu, H.; Kobayashi, J.; Ohizumi, Y. Agelasidine-A, a novel sesquiterpene possessing antispasmodic activity from the Okinawa Sea sponge Agelas sp. Tetrahedron Lett. 1983, 24, 4105-4108. [CrossRef]

117. Pettit, G.R.; Xu, J.P.; Gingrich, D.E.; Williams, M.D.; Doubek, D.L.; Chapuis, J.C.; Schmidt, J.M. Isolation and structure of agelagalastatin from the Papua New Guinea marine sponge Agelas sp. Chem. Commun. 1999, 30, 915-916. [CrossRef]

118. Zhang, H.W.; Zhao, Z.P.; Wang, H. Cytotoxic natural products from marine sponge-derived microorganisms. Mar. Drugs 2017, 15, 68. [CrossRef] [PubMed]

(C) 2017 by the authors. Licensee MDPI, Basel, Switzerland. This article is an open access article distributed under the terms and conditions of the Creative Commons Attribution (CC BY) license (http://creativecommons.org/licenses/by/4.0/). 